University of Nebraska - Lincoln

DigitalCommons@University of Nebraska - Lincoln

Papers in the Earth and Atmospheric Sciences

Earth and Atmospheric Sciences, Department

4-2006

\title{
Geochronology and Mammalian Biostratigraphy of Middle and Upper Paleocene Continental Strata, Bighorn Basin, Wyoming
}

\author{
Ross Secord \\ University of Nebraska-Lincoln, rsecord2@unl.edu \\ Philip D. Gingerich \\ University of Michigan - Ann Arbor, gingeric@umich.edu \\ M. Elliot Smith \\ University of Wisconsin - Madison \\ William C. Clyde \\ University of New Hampshire \\ Peter Wilf \\ Pennsylvania State University \\ See next page for additional authors
}

Follow this and additional works at: https://digitalcommons.unl.edu/geosciencefacpub

Part of the Earth Sciences Commons

Secord, Ross; Gingerich, Philip D.; Smith, M. Elliot; Clyde, William C.; Wilf, Peter; and Singer, Brad S., "Geochronology and Mammalian Biostratigraphy of Middle and Upper Paleocene Continental Strata, Bighorn Basin, Wyoming" (2006). Papers in the Earth and Atmospheric Sciences. 190.

https://digitalcommons.unl.edu/geosciencefacpub/190

This Article is brought to you for free and open access by the Earth and Atmospheric Sciences, Department of at DigitalCommons@University of Nebraska - Lincoln. It has been accepted for inclusion in Papers in the Earth and Atmospheric Sciences by an authorized administrator of DigitalCommons@University of Nebraska - Lincoln. 


\section{Authors}

Ross Secord, Philip D. Gingerich, M. Elliot Smith, William C. Clyde, Peter Wilf, and Brad S. Singer 


\title{
American Journal of Science
}

\author{
APRIL 2006
}

\section{GEOCHRONOLOGY AND MAMMALIAN BIOSTRATIGRAPHY OF MIDDLE AND UPPER PALEOCENE CONTINENTAL STRATA, BIGHORN BASIN, WYOMING}

\author{
ROSS SECORD****, , PHILIP D. GINGERICH**, M. ELLIOT SMITH***, \\ WILLIAM C. CLYDE ${ }^{\ddagger}$, PETER WILF ${ }^{\S}$, and BRAD S. SINGER***
}

\begin{abstract}
The Bighorn Basin of northwestern Wyoming preserves one of the most complete records of middle Paleocene to lower Eocene continental biota. The geochronology of this important interval depends partly on numerical calibration of the geomagnetic polarity time scale (GPTS), but the middle and late Paleocene parts of the GPTS have been poorly constrained radioisotopically. A new volcanic ash from the northern Bighorn Basin provides the first radioisotopic age for upper middle Paleocene strata (upper Selandian) and is an important calibration point for the base of polarity Chron C26n and the Selandian-Thanetian stage boundary in the GPTS. Sanidine from the ash has a weighted mean age of $59.00 \pm 0.30(2 \sigma) \mathrm{Ma}$, based on twenty-three ${ }^{40} \mathrm{Ar} /{ }^{39} \mathrm{Ar}$ bulk laser-fusion analyses. The ash corroborates the revised age estimate for the base of Chron C26n in the most recent geomagnetic polarity time scale (GPTS-04) and confirms that C26n is older than depicted in the 1995 GPTS.

We place Paleocene mammalian biozones in the Bighorn Basin into a refined geochronologic framework. These biozones are the primary basis for biostratigraphic correlation of middle and upper Paleocene continental deposits in North America. New paleomagnetic data provide synchronous tie points for correlation among three stratigraphic sections in the northern Bighorn Basin and to the GPTS. Paleomagnetic correlation, study of new fossil material, review of known faunas, and refined stratigraphy enable us to reevaluate several biozones. We define three new zones based on first occurrences of taxa: the Phenacolemur (Ti-4b), Probathyopsis (Ti-5a, revised), and Copecion (Cf-3, revised) zones. The Phenacolemur zone includes some faunas previously placed in the Plesiadapis churchilli and Plesiadapis fodinatus zones (Ti-4 and Ti-5a, respectively). The Probathyopsis zone replaces the $P$. fodinatus zone and the Copecion zone replaces the Phenacodus-Ectocion acme zone (Cf-3).

Seven of the biozones considered here are subdivisions of the Tiffanian landmammal age. The Tiffanian was originally typified by the Mason Pocket fauna in southwestern Colorado, but it is now much better known from faunas in the northern Bighorn Basin. Biostratigraphic evidence and new paleomagnetic data from the Bighorn Basin indicate that Mason Pocket is considerably older than was previously recognized and occurs in Chron C26r, rather than C25r. The geochronologic framework presented here helps to constrain the temporal ranges of species that occur in the middle and late Tiffanian, and it allows the Bighorn Basin record to be better compared to other faunal, floral, and paleoclimate records, both regionally and globally.
\end{abstract}

\footnotetext{
*Department of Paleobiology, NMNH, Smithsonian Institution, P.O. Box 37012, NHB MRC 121, Washington, D.C. 20013-7012, USA

**Geological Sciences and Museum of Paleontology, University of Michigan, Ann Arbor, Michigan 48109-1079, USA

***Department of Geology and Geophysics, University of Wisconsin, 1215 West Dayton Street, Madison, Wisconsin 53706, USA

${ }^{\ddagger}$ Department of Earth Sciences, University of New Hampshire, Durham, New Hampshire 03824, USA

$\$$ Department of Geosciences, Pennsylvania State University, University Park, Pennsylvania 16802, USA

${ }^{\dagger}$ Present address of corresponding author: Museum of Paleontology, University of Michigan, Ann Arbor, Michigan 48109-1079, USA; secordr@si.edu
} 
INTRODUCTION

Continental sedimentary deposits in North America contain rich records of Paleogene faunas and floras (for example, Savage and Russell, 1983; Wing and others, 1995; Hartman and Roth, 1998; Wilf and others, 1998; Graham, 1999; Lofgren and others, 2004). Placing these into a global geochronologic context, however, has long been hindered by difficulties in correlating continental strata to the marine sequences that are used to define series and stage boundaries. Consequently, many continental workers relied on fossil mammals for correlation and developed a biochronology ${ }^{1}$ largely independent of the marine record (Wood and others, 1941). In the last few decades, however, the ability to recognize paleomagnetic reversals in sedimentary rocks has provided nearly synchronous time-lines that allow the correlation of continental strata to the geomagnetic polarity time scale (GPTS) (Harland and others, 1982, 1990; Cande and Kent, 1992, 1995; Agterberg, 2004; Luterbacher and others, 2004; Ogg and Smith, 2004). In addition, radioisotopic ages from volcanogenic minerals have greatly facilitated the correlation of continental sedimentary strata to the GPTS and are the basis for its numerical calibration. In many instances, continental biostratigraphies can now be placed into a geochronologic context.

Until now, no radioisotopic data useful for GPTS calibration were available for the middle or upper Paleocene (Selandian and Thanetian, respectively: Luterbacher and others, 2004). Recent revision of the Paleocene GPTS (GPTS-04, Ogg and Smith, 2004) relied on two constraints: a recalculated radioisotopic age of $65.5 \mathrm{Ma}$ for the Cretaceous-Paleogene (K-P) boundary and new duration estimates for polarity chrons based on cyclicity attributed to orbital forcing in the marine sedimentary record (Herbert and others, 1995; Röhl and others, 2001, 2003; Luterbacher and others, 2004). Age estimates for Paleocene chron boundaries in GPTS-04 are all older than those in the previous GPTS (GPTS-95, Cande and Kent, 1992, 1995).

In GPTS-95, Paleocene chron boundaries were calibrated by interpolating between radioisotopic anchor points of $65 \mathrm{Ma}$ and $55 \mathrm{Ma}$ for the K-P and PaleoceneEocene (P-E) boundaries, respectively, using a spline function. Subsequent normalization of ${ }^{40} \mathrm{Ar} /{ }^{39} \mathrm{Ar}$ ages for the K-P boundary to ages of 28.32 and 28.02 Ma for the Taylor Creek Rhyolite and Fish Canyon Tuff monitor standards, however, resulted in an older age of $65.51 \pm 0.1 \mathrm{Ma}$ (Obradovich and Hicks, 1999; Hicks and others, 2002, pp. 42-43). Additionally, in GPTS-95 the P-E boundary was considered to be approximately equivalent to the NP9-NP10 (marine nannoplankton zones) boundary in DSDP Hole 550, but is now placed at the beginning of a pronounced negative carbon isotope excursion (CIE) (Luterbacher and others, 2004), which is slightly older and occurs in NP9 (see Wing and others, 2000, pp. 201-203, for discussion of problems with radioisotopic ages near the $\mathrm{P}-\mathrm{E}$ boundary).

In GPTS-04, Paleocene chrons and the P-E boundary were calibrated by the upward scaling of orbitally-tuned chron durations from a revised age of $65.5 \mathrm{Ma}$ for the K-P boundary. This "stacking" of chron durations resulted in a revised age of $55.8 \pm 0.2$ Ma for the P-E boundary, which is older than most previous estimates of 55.5 to $55.0 \mathrm{Ma}$ (for example, Swisher and Knox, 1991; Cande and Kent, 1992, p. 13,934, 1995; Berggren and others, 1995, pp. 135-136; Gingerich, 2003, p. 467). Because orbital tuning relies on a complete record of cycles, however, it provides minimum estimates of chron durations, and 55.8 Ma may best be viewed as a maximum age estimate for the P-E boundary.

1. "Biochronology" as used here refers to the organization of geologic time according to the process of organic evolution (Berggren and Van Couvering, 1978), compared to biostratigraphy which is the characterization and correlation of strata on the basis of fossil content. Biochrons are often composites of regional faunas correlated on the basis of faunal content. 


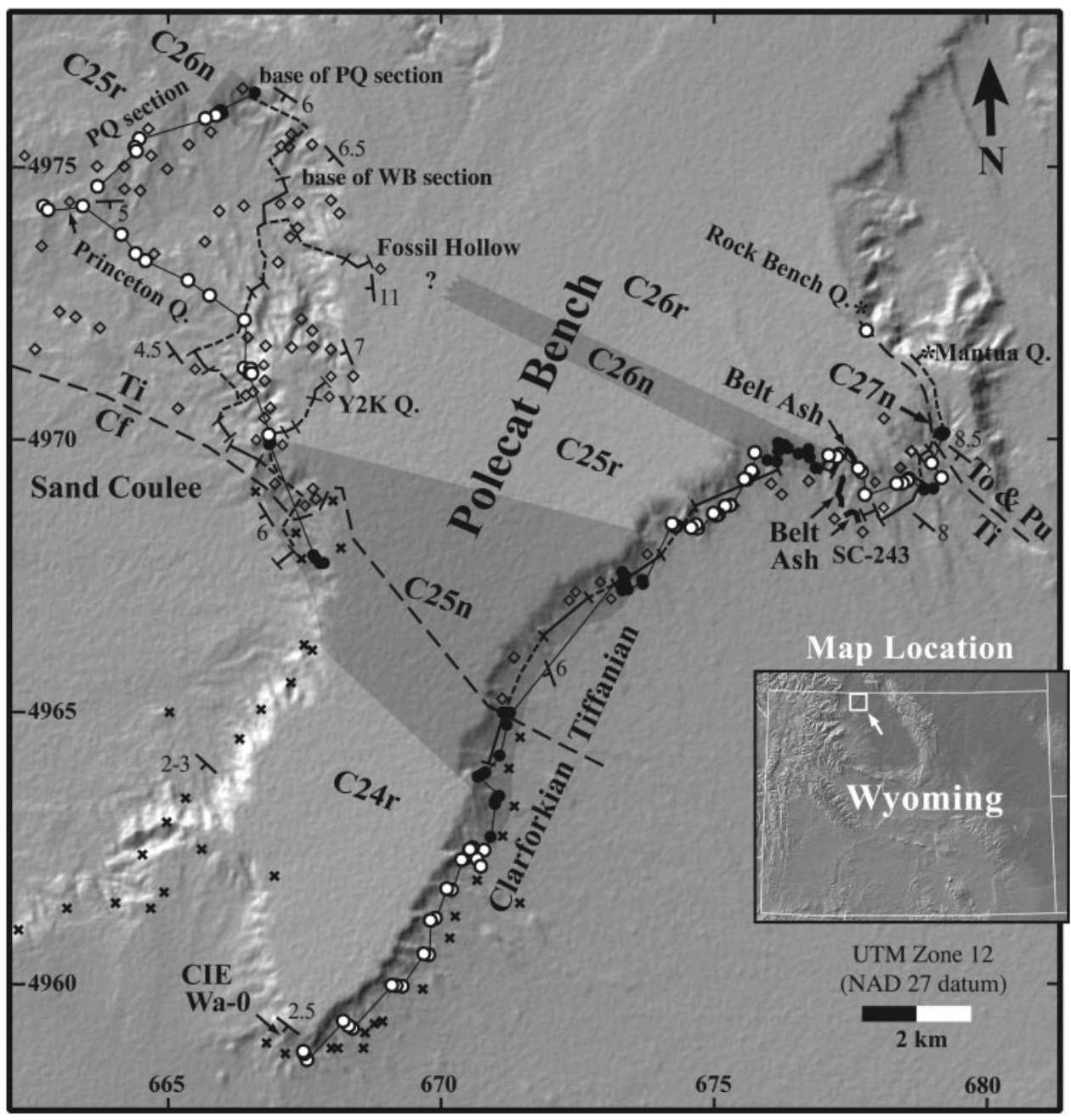

Fig. 1. Shaded-relief map (USGS) of Polecat Bench in the northern Bighorn Basin, Wyoming, showing Paleocene mammal localities, locations of paleomagnetic samples collected by Butler and others (1981, 1987) and in this study (Princeton Quarry section, upper left), projection of magnetic polarity zones, locations of measured sections used in figure 2, and location of the Belt Ash (UTM: 12T, E 677341, N 4969125, NAD 1927). Fossils were collected along the margins of Polecat Bench, in Sand Coulee, and in Foster Gulch (not shown on map, see Appendix A). Top of polarity zone C25n on the west side of Polecat Bench estimated from stratigraphic thickness. Measured sections shown as thick solid lines and bed traces as short dashes; land-mammal age boundaries as long dashes; paleomagnetic sample sites connected by thin solid lines. Arrows point to outcrops containing the Belt Ash. UTM Coordinates in kilometers. Abbreviations: $\mathrm{CIE}=$ carbon isotope excursion; $\mathrm{Cf}=$ Clarkforkian; $\mathrm{Pu}=$ Puercan; $\mathrm{Ti}=$ Tiffanian; $\mathrm{To}=$ Torrejonian; $\mathrm{Wa}=$ Wasatchian; open circle $=$ normal polarity site; solid circle $=$ reversed polarity site; diamond = Tiffanian locality, cross = Clarkforkian locality; Q. = Quarry.

Discovery and age determination of a new volcanic ash in the northern Bighorn Basin of Wyoming provides the first radioisotopic calibration point for the middle or upper Paleocene from a stratigraphic sequence with known paleomagnetism (we call this ash the Belt Ash in honor of Edward S. Belt for his contributions to stratigraphy in the Rocky Mountain region). The Belt Ash occurs in the Polecat Bench sequence (figs. 1 and 2) $40 \mathrm{~m}$ stratigraphically below the base of polarity zone C26n, which is equated to the Selandian-Thanetian stage boundary in GPTS-04. The radioisotopic age of the 


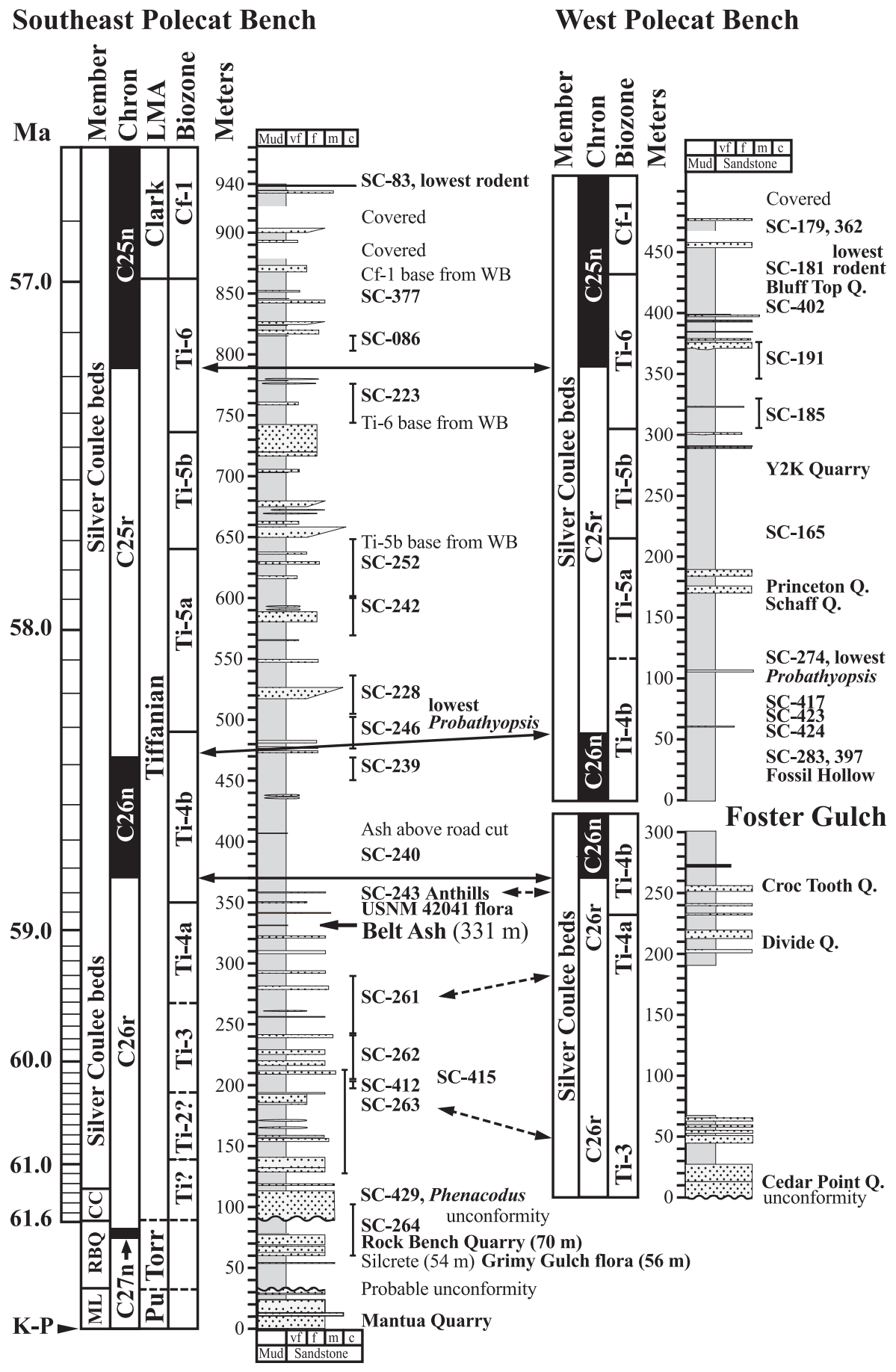

Fig. 2. Correlation of West Polecat Bench and Foster Gulch sections to Southeast Polecat Bench section (see Appendix A). Levels for Chron C26n, and Princeton and Schaff quarries in West Polecat Bench section are estimated from Princeton Quarry section (fig. 8) based on bed trace between sections (fig. 1). Foster Gulch section is composite (see "Magnetostratigraphy" section of text). Meter levels relative to K-P boundary. Age scale in 0.1 myr intervals based on cubic spline interpolation between polarity zone 
Belt Ash is important for: (1) testing previous correlation of the Bighorn Basin magnetostratigraphic record to the GPTS by Butler and others $(1981,1987)$; (2) testing the revised age for the C26r-C26n Chron boundary in GPTS-04; and (3) for future age calibration of Chron C26n and the Selandian-Thanetian stage boundary in the GPTS.

Paleomagnetic samples were collected and analyzed from 49 discrete sites in two stratigraphic sections in the northern Bighorn Basin in areas or at levels that had not previously been sampled. These data were combined with data from previous paleomagnetic studies (Butler and others, 1981, 1987) to correlate key fossil localities. The radioisotopic and magnetostratigraphic data presented here, along with new collections of mammal fossils, new studies of previous collections, and a revised lithostratigraphic framework, place biozones in the Bighorn Basin into a refined geochronologic context. These biozones have been used to subdivide the Tiffanian and Clarkforkian land-mammal ages and have been the basis for regional biostratigraphic correlation of middle and upper Paleocene strata (Gingerich, 1975, 1976, 1983a, 2001; Rose, 1980, 1981; Archibald and others, 1987; Gingerich and Clyde, 2001; Lofgren and others, 2004).

Land-mammal ages ${ }^{2}$ were first conceived as temporal units defined by faunal content and were only loosely tied to stratigraphic sections (Wood and others, 1941). In recent years, however, there has been an effort to bring land-mammal ages into compliance with the North American Stratigraphic Code (NACSN, 1983, 2005) and the International Stratigraphic Guide (ISSC, 1994). The two land-mammal ages evaluated here differ in their degree of conformity to these codes. The Clarkforkian land-mammal age meets the criteria necessary to be a valid chronostratigraphic stage and geochronologic age (ISSC, 1994; NACSN, 2005). Its stratigraphic limits and faunal content are rigorously defined in the Clarks Fork Basin, a sub-basin within the northern Bighorn Basin, which is the type area (Rose, 1980, 1981; Gingerich, 2001). The Tiffanian land-mammal age, however, cannot yet be viewed as a valid chronostratigraphic unit because neither its lower nor upper boundary occurs in the type area in southwestern Colorado (Lofgren and others, 2004, fig. 3.2). The NACSN notes that both boundaries need not be in the same region, but certainly at least one should occur in the type area. The lower and upper boundaries of the Tiffanian are, however, stratigraphically well constrained in the Hanna Basin of central Wyoming (Higgins, 2003) and in the Bighorn Basin (Rose, 1980, 1981; Gingerich, 2001), respectively. The Bighorn Basin contains the most complete continuous record of middle and late Tiffanian faunas known. Thus, the Polecat Bench sequence (fig. 1) serves as an informal reference section for the Tiffanian. The work presented here places the middle and upper Tiffanian into a refined chronostratigraphic context and brings it closer to conformity with the stratigraphic codes.

2. We use a lower case "age" to indicate informal status; temporal references to land-mammal ages refer to relative age.

\footnotetext{
boundaries calibrated to GPTS-04 (fig. 6). Note that intervals become longer up-section because of faster accumulation rates. All rocks shown are Fort Union Formation. "Base from WB" refers to instances where a biozone boundary was better constrained in the West Bench Section and correlated to the Southeast Bench section based on stratigraphic position. "Ash above road cut" is volcanic ash in which sanidine crystals were not found. Solid and dashed arrows show magnetostratigraphic and biostratigraphic tie points, respectively, between sections (see Appendix A). Magnetostratigraphy (except Princeton Quarry and Foster Gulch sections) adapted from Butler and others $(1981,1987)$. Biozone symbols explained in figure 3. SC symbols denote University of Michigan vertebrate localities. Vertical bars show thickness of locality. Abbreviations: $\mathrm{CC}=$ Chert Conglomerate; $\mathrm{ML}=$ Mantua Lentil; $\mathrm{RBQ}=$ Rock Bench Quarry beds; LMA = land-mammal age; Clark $=$ Clarkforkian; $\mathrm{Pu}=$ Puercan; Torr $=$ Torrejonian .
} 
We use the Belt Ash to test revision of the Paleocene GPTS-04 by comparing the fit of its radioisotopic age to magnetostratigraphic age predictions using data from GPTS-04 and GPTS-95 (Cande and Kent, 1992, 1995). We then present new paleomagnetic data that help to constrain the geochronologic ages of important fossil localities at Polecat Bench and in Foster Gulch, about $40 \mathrm{~km}$ to the southeast. We next present a revised biostratigraphy that includes the definition of three new biozones, two of which replace existing zones, and a reevaluation of several zone boundaries. We then use the ages of magnetic reversals and the CIE at the Paleocene-Eocene boundary to calibrate Paleocene biozone boundaries. Lastly, we discuss the Tiffanian and Clarkforkian land-mammal ages and suggest a revised, older age for Mason Pocket, the principal fauna from the type Tiffanian in southwestern Colorado.

\section{ABBREVIATIONS AND SYMBOLS USED IN TEXT}

AMNH = American Museum of Natural History, New York, USA; Cf $=$ Clarkforkian biozone; DGPS $=$ Differential Global Positioning System; DSDP $=$ Deep Sea Drilling Project; FG = University of Michigan Foster Gulch locality; GPTS = Geomagnetic polarity time scale; ISSC = International Subcommission on Stratigraphic Classification of the International Commission on Stratigraphy; K-P = CretaceousPaleogene boundary; $\mathbf{M a}=$ mega annum; MSWD = mean squared weighted deviation; myr = million years; NACSN $=$ North American Commission on Stratigraphic Nomenclature; P-E = Paleocene-Eocene; PETM = Paleocene-Eocene boundary thermal maximum; RBQ = Rock Bench Quarry; $\mathbf{S C}=$ University of Michigan locality in Sand Coulee or Polecat Bench; TCs = Taylor Creek Rhyolite sanidine standard crystals; $\mathbf{T i}=$ Tiffanian biozone; $\mathbf{U M}=$ University of Michigan Museum of Paleontology, Michigan, USA; USNM = Smithsonian Institution, National Museum of Natural History, D.C., USA; UTM = Universal Transverse Mercator; VGP = virtual geomagnetic pole; YPM-PU = Yale Peabody Museum (Connecticut, USA) specimen collected by Princeton University; $\boldsymbol{\sigma}=$ standard deviation.

\section{LITHOSTRATIGRAPHIC FRAMEWORK}

\section{Lithologic Units}

Stratigraphic sections from the southeastern and western sides of Polecat Bench, and Foster Gulch are shown in figure 2. Stratigraphic thicknesses in the lower $350 \mathrm{~m}$ of the Fort Union Formation on Polecat Bench were measured using a Differential Global Positioning System (DGPS) with an accuracy of about $\pm 1.0 \mathrm{~m}$ easting, $\pm 1.5 \mathrm{~m}$ northing, and 1 to $3 \mathrm{~m}$ elevation (see Gingerich, 2001, pp. 43-46, for more detail). Thicknesses were calculated by tracing marker beds with the DGPS, using traces to calculate attitudes, and using attitudes and elevation to calculate thicknesses between marker beds and interspersed localities. This technique yielded an overall section thickness that was less than previous estimates (Gingerich, 2001; Secord, ms, 2004). The greater thicknesses in previous estimates were probably due in part to not averaging dips between stations in a section in which dip generally decreases upsection. Composite thicknesses for strata above $350 \mathrm{~m}$ were based primarily on plane table, alidade, and Jacob staff measurements. Paleomagnetic sections measured by Butler and others (1981) on both sides of Polecat Bench were adapted to our sections using unpublished field data.

The Fort Union Formation (equivalent to the Polecat Bench Formation of Jepsen, 1940) and the overlying Willwood Formation both contain Paleocene strata in the northern Bighorn Basin. The following descriptions refer to the main stratigraphic sequence on the southeastern side of Polecat Bench (fig. 1), unless otherwise noted. The Fort Union and Willwood formations are $\sim 1150$ and $\sim 1100 \mathrm{~m}$ thick, respectively. The Fort Union Formation consists primarily of drab gray mudstones, interbedded with yellow-gray to gray-orange, fine- to medium-grained sandstones and carbonaceous 
shales. These rocks were deposited primarily in reducing environments on poorlydrained floodplains by meandering rivers and in floodplain swamps (Jepsen, 1940; Hickey, 1980; Kraus, 1997). The Fort Union Formation rests on the Lance Formation and can be distinguished from it by the presence of laterally continuous lignites (Hickey, 1980, p. 44). The formational contact is placed at the first lignite, which approximately coincides with the K-P boundary based on pollen and vertebrates (Hickey, 1986, pp. 288-289). The contact appears to be locally conformable, although Puercan mammals are only known from sandstones of the Fort Union Formation that incise underlying strata and sometimes channel into the Lance Formation (Hickey, 1980, p. 37).

In contrast to the Fort Union Formation, the Willwood Formation was deposited predominantly in seasonally dry, oxidizing environments (Bown and Kraus, 1981; Kraus, 1997; Davies-Vollum, 2001). Like the Fort Union Formation, deposition occurred mostly on floodplains. The Willwood Formation is distinguished from the Fort Union Formation primarily by the prevalence of brightly colored red beds (Van Houten, 1944, p. 176) interpreted to be the B horizons of paleosols (Bown and Kraus, 1981, p. 7; Kraus, 1997, pp. 391-392, fig. 5). The transition from drab beds to persistent red beds coincides with the Paleocene-Eocene boundary thermal maximum (PETM) ( $\sim$ Clarkforkian-Wasatchian boundary) in most of the Bighorn Basin, but on Polecat Bench it occurs 1.0 myr earlier in the early Clarkforkian (Rose, 1981, pp. 8-12; Wing and others, 2000, pp. 200-201). Thus, the formational contact is highly diachronous. Global temperature increased by 5 to $8^{\circ} \mathrm{C}$ during the PETM, which coincides with the CIE, and is known from both marine (Zachos and others, 2001, fig. 2) and continental records (Koch and others, 1992, 1995; Fricke and others, 1998; Magioncalda and others, 2004). The development of Eocene red beds is generally attributed to an increase in temperature and seasonal dryness (Bown and Kraus, 1981). The earlier development of red beds on Polecat Bench may have been the result of better drained soils in combination with a gradual shift to a warmer, seasonally drier climate.

Three lithologically distinct, informal units were recognized by Jepsen (1940) in the Fort Union Formation on Polecat Bench: the Mantua Lentil, the Rock Bench quarry (RBQ) beds, and the Silver Coulee beds (fluvial member of Hickey, 1980, pp. 37-38). The units reach maximum thicknesses of approximately 45,47 , and $800 \mathrm{~m}$, respectively. The Mantua Lentil is a lenticular-shaped series of laterally discontinuous, fine- to medium-grained sandstone bodies that thins locally and pinches out to the north and south. The RBQ beds overlie the Mantua Lentil and consist of a series of dark carbonaceous mudstones and shales with subordinate sandstone ribbons and lignite. The RBQ beds and Mantua Lentil were equated with the Lebo Member of the Fort Union Formation by Stow (1938, p. 736), a correlation tentatively followed by Hickey (1980, p. 37). An additional unit, a conglomeratic sandstone (hence informally referred to as the "chert conglomerate"), unconformably overlies the RBQ beds (fig. 2). Jepsen (1930, p. 479, fig. 1 and p. 488) referred to these beds as "quartzite conglomerates," but did not later list them as a separate unit (Jepsen, 1940). The chert conglomerate reaches a thickness of $\sim 25 \mathrm{~m}$ and contains local lenses of light to dark gray, rounded clasts of microcrystalline quartz. The clasts are granule- to pebble-size and primarily matrix-supported on Polecat Bench, but are frequently clast-supported in exposures farther to the southeast.

The Silver Coulee beds are $\sim 800 \mathrm{~m}$ thick on Polecat Bench and consist primarily of gray mudstones, interbedded with yellow-gray to gray-orange fine- to mediumgrained ribbon sandstones and carbonaceous shales. Shelf-forming beds consisting of intergradational argillaceous limestone lenses and nodules, and calcareous siltstones and fine-grained sandstones are also common. There is no evidence for substantial unconformities or significant hiatuses above the chert conglomerate in the Silver Coulee beds or lower Willwood Formation on Polecat Bench. No middle or late 
Tiffanian biozones have been recognized outside the Bighorn Basin that are not present in the Bighorn Basin. Similarly, all the paleomagnetic polarity zones recognized in the middle and late Paleocene GPTS are present and are broadly similar in relative thicknesses to those recognized in the marine record (Cande and Kent, 1992, 1995; Ogg and Smith, 2004). Based on this biostratigraphic and geomagnetic continuity, the depositional record in the Silver Coulee beds appears to be relatively complete.

Three additional informal members were recognized by Hickey (1980, pp. 38-40) in the Fort Union Formation: the lacustrine (later formalized as the Belfry Member by Yuretich and others, 1984), conglomerate (Beartooth Conglomerate of DeCelles and others, 1991), and paludal members. Hickey and Yuretich (1997) described six cycles of tabular sandstone and micrite in the Belfry Member, which they interpreted as lake deposits. The sandstone-micrite couplets are intercalated with mudstones and lignites deposited on floodplains. The Belfry Member intergrades with the Silver Coulee beds along the northwest margin of Polecat Bench but is better represented near Belfry, Montana, $\sim 30 \mathrm{~km}$ to the northwest. The Beartooth conglomerate occurs along the eastern margin of the Beartooth Range in the Clarks Fork Basin in Wyoming and Montana (Hickey, 1980, fig. 1; DeCelles and others, 1991, fig. 1). A model of the unroofing history of the Beartooth Uplift was developed by DeCelles and others (1991), based on the conglomerate. The paludal member occurs along the axis of the Bighorn Basin in Montana, northwest of Polecat Bench, and consists of carbonaceous mudstone, thin sandstone, and coal. Neither the paludal member nor the Beartooth conglomerate occurs at Polecat Bench or in Foster Gulch (see Appendix A).

\section{Biostratigraphic Constraints on Lithologic Units}

Biostratigraphic constraints on the three lowest lithologic units in the Fort Union Formation are important for understanding the depositional history of the Polecat Bench sequence. These units have a total thickness of only $\sim 130 \mathrm{~m}$, but span $\sim 4$ myr of the early Paleocene ( $\mathrm{Pu}$, Torr, fig. 2), in contrast to the $\sim 800 \mathrm{~m}$ thick overlying Silver Coulee beds, which span $\sim 4$ myr of the middle and late Paleocene (Tiffanian and early Clarkforkian, fig. 2). The base of the Mantua Lentil is temporally well constrained by Mantua Quarry (fig. 2), which correlates to the early part of the Puercan (Pu-1) land-mammal age (Jepsen, 1940; Archibald and others, 1987; Lofgren and others, 2004). Rock Bench Quarry occurs in the upper part of the RBQ beds, $70 \mathrm{~m}$ above the K-P boundary (fig. 2), and correlates to the Torrejonian land-mammal age (Rose, 1981, pp. 145-148; Archibald and others, 1987, p. 30; Lofgren and others, 2004, table 3.1). It occurs in polarity zone C27r (Butler and others, 1987, p. 655), indicating that it is 2.0 to 2.5 myr younger than Mantua Quarry and at least 1 myr younger than latest Puercan (Pu-3) (Lofgren and others, 2004, fig. 3.2). This implies one or more significant hiatuses somewhere between the quarries, extremely slow rates of sediment accumulation, or both. A darkly stained, hummocky surface at the top of the Mantua Lentil in the vicinities of Rock Bench and Mantua quarries is coincident with an abrupt change in lithology, and suggests a significant unconformity between the Mantua Lentil and RBQ beds (fig. 2). Hickey (1980, p. 44) provisionally placed the PuercanTorrejonian boundary within the RBQ beds, between the Grimy Gulch flora (LJH loc. 7861) and Rock Bench Quarry (fig. 2), at a level where mammals are not known. Hickey's placement of the boundary relied on a Puercan age for the Grimy Gulch flora, but differences between Puercan and Torrejonian floras are not well established, and better age control is needed for confident placement of the boundary.

The chert conglomerate is latest Torrejonian or Tiffanian in age, as indicated by a newly discovered Phenacodus molar (UM 112580, $\mathrm{M}_{2}$; length $=11.7$, width $=9.3$ ) from the upper part of the unit (fig. 2). The $\mathrm{M}_{2}$ is within the size range of $P$. grangeri, known from middle Tiffanian (Ti-3; fig. 3) and younger faunas, but may also be within the size range of an undescribed species from a late Torrejonian fauna from the Hanna Basin of southeastern Wyoming (Higgins, 2003, fig. 9). The latter differs from P. grangeri in 

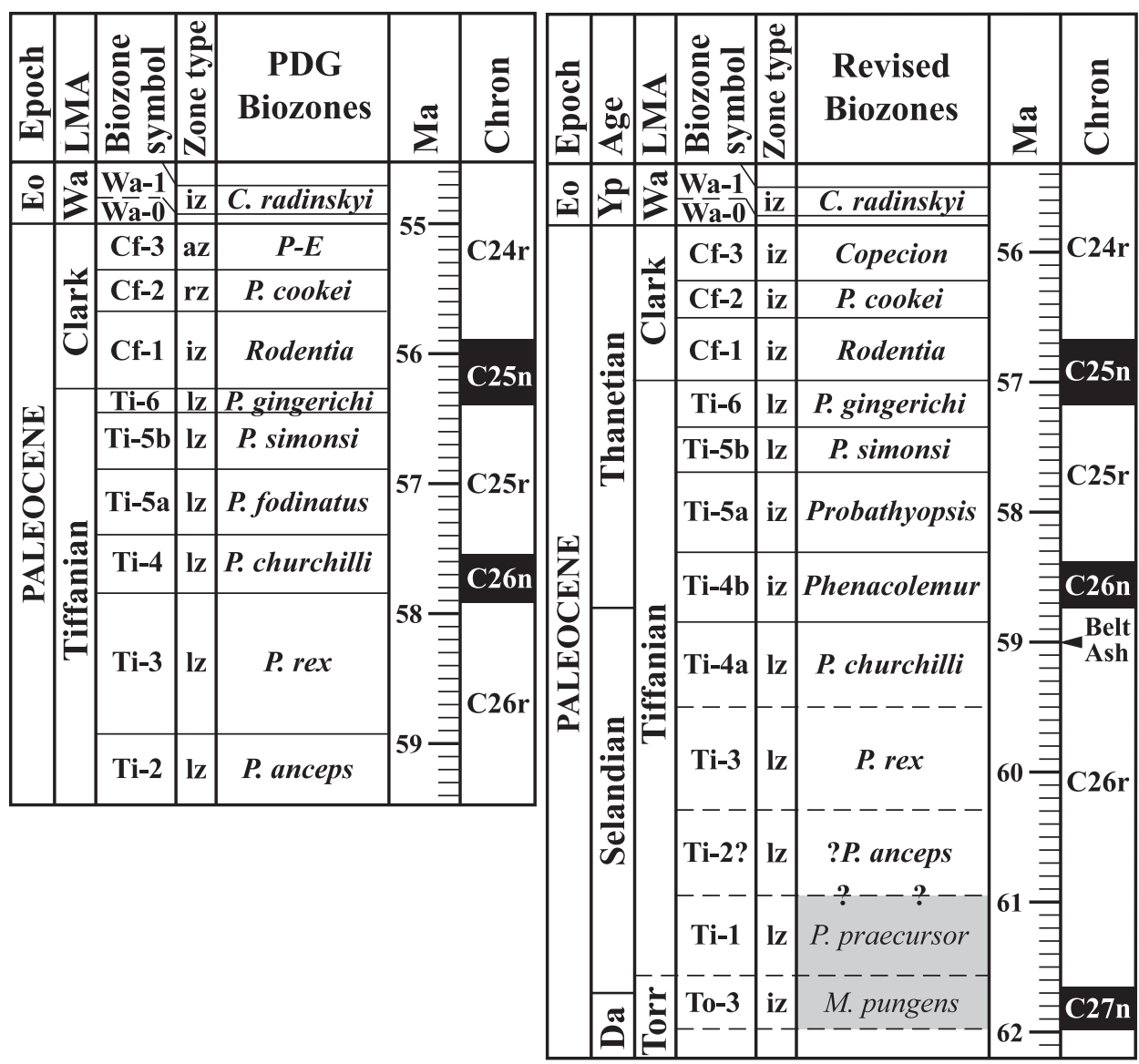

Fig. 3. Comparison of biozonation of Gingerich (2001, 2003) (PDG, left), calibrated to Cande and Kent (1995) in part, with revised biozonation calibrated to GPTS-04 (right). Biozones are named after taxon that defines base; succeeding taxon defines top. Revised biozone boundaries for Ti-2 to Cf-3 calibrated by cubic spline interpolation (fig. 6) between polarity chron reversal ages of Ogg and Smith (2004) and P-E boundary age of Luterbacher and others (2004). Shaded intervals represent biozones in the San Juan (M. pungens; Williamson, 1996; Lofgren and others, 2004) and Crazy Mountains (p. praecursor; Gingerich, 1976, 1983; Hartman and Krause, 1993) basins that have not been recognized in the northern Bighorn Basin. Ages for bases of To-3 to Ti-1 estimated from positions relative to magnetic polarity chrons in Williamson (1996) and Butler and others (1987). Zone types follow ISSC (1994) and NACSN (2005): interval zones (iz) based on first occurrences of taxa not closely related to preceding or succeeding zone taxa; lineage zones (lz) based on evolutionary lineages of Plesiadapis; taxon range zone (rz) based on the total range of Plesiadapis cookei; and the abundance zone (az) on abundance of Phenacodus and Ectocion. Abbreviations: C. = Cardiolophus; M. = Mixodectes; $P .=$ Plesiadapis; $P-E=$ Phenacodus-Ectocion; LMA = land-mammal age; Clark = Clarkforkian; Torr $=$ Torrejonian; $\mathrm{Wa}=$ Wasatchian $; \mathrm{Eo}=$ Eocene $; \mathrm{Da}=$ Danian; $\mathrm{Yp}=$ Ypresian .

having a narrower $\mathrm{P}_{4}\left(\mathrm{P}_{4}\right.$, length $=10.5$, width $=6.7 \mathrm{~mm}$; Higgins, ms, 2000). Also pertinent is a dentary with imprecise locality data tentatively identified as $P$. anceps (YPM-PU 17816, Gingerich, 1976, p. 27), collected at the level of the chert conglomerate or higher, that suggests an early Tiffanian age (Ti-2). If the chert conglomerate is Ti-2 in age, a significant hiatus eliminating Ti-1 is implied at its base, which incises the RBQ beds (fig. 2). The duration of Ti-1 is not well-constrained but it can be tentatively bracketed by an age of $61.65 \pm 0.2$ Ma for the C27n-C26r Chron reversal (GPTS-04), which is at or just below the Torrejonian-Tiffanian boundary (Butler and others, 1987, pp. 654-655; Lofgren and others, 2004, fig. 3.2), and an age of $61.06 \pm 0.33 \mathrm{Ma}$ for an ash from North Dakota positioned 6 to $10 \mathrm{~m}$ below a mammal locality tentatively 
correlated to Ti-2 (Belt and others, 2004, p. 128). These data suggest that the duration of Ti-1 was not more than $\sim 1.0$ myr.

The Silver Coulee beds on Polecat Bench and in Foster Gulch are the source of nearly all Tiffanian fossils included in this study. Collections were made by crews from Princeton University and the University of Michigan, and consist of over 6500 mammal jaws and teeth. Few specimens are known from the lower Silver Coulee beds on Polecat Bench, but the base of the unit is probably no older than early Tiffanian, based on the age of the underlying chert conglomerate discussed above. The Silver Coulee beds in Foster Gulch unconformably overlie the Late Cretaceous Lance Formation. These beds are no older than the P. rex zone (Ti-3; fig. 3) (Gingerich, 1983a, fig. 2, "d" area), based on Cedar Point Quarry that occurs only $\sim 10 \mathrm{~m}$ above the unconformity (fig. 2). Although the Silver Coulee beds are mostly Tiffanian in age, the uppermost part is early Clarkforkian (Cf-1) on Polecat Bench, and in Foster Gulch the beds span the entire Clarkforkian.

The Bear Creek fauna is the only fauna known from Hickey's (1980) paludal member. It is early Clarkforkian in age (Cf-1). It is especially important because it comes from the roof of a coal mine and represents a rarely sampled environment (Simpson, 1928, 1929a, 1929b; Gunnell and Bartels, 2001, pp. 150-151). Floras and a small collection of fossil mammals indicate a Clarkforkian age for Hickey's overlying conglomerate member which crops out west of Polecat Bench along the Beartooth front (Hickey, 1980, fig. 2; Gingerich, 1983a, fig. 2). Neither vertebrate nor plant fossils have been described from the main body of the Belfry Member, but gastropods and pelecyopds are common (Yuretich and others, 1984, p. 842).

$$
{ }^{40} \text { AR } /{ }^{39} \text { AR GEOCHRONOLOGY OF THE BELT ASH }
$$

The Belt Ash was discovered by one of us (P. Wilf) in a series of carbonaceous shales in the Silver Coulee beds on the southeastern side of Polecat Bench (fig. 1). The ash is 2 to $3 \mathrm{~cm}$ thick, is composed of $<5$ percent volcanic phenocrysts encased in a matrix of bentonitic clay, and can be traced laterally for more than a kilometer. It occurs approximately $40 \mathrm{~m}$ below the base of polarity zone C26n, in the upper part of C26r (fig. 2). With respect to biozones, it occurs in the upper part of the P. churchilli zone (Ti-4a; fig. 3, right column), $30 \mathrm{~m}$ below the base of the Phenacolemur zone (Ti-4b). A macroflora (USNM locality 42041; "Skeleton Coast") of more than 850 identified specimens was recently collected $20 \mathrm{~m}$ above the Belt Ash and is being studied by P. Wilf.

Sanidine phenocrysts 75 to $125 \mu \mathrm{m}$ in diameter were separated from ash matrix by crushing, using heavy liquids, handpicking under refractive-index oil (see Smith and others, 2003), and ultrasonic cleaning in 10 percent HF. Crystals were irradiated at Oregon State University where they received a fast neutron dose of $\sim 5 \times 10^{18}$ neutrons $/ \mathrm{cm}^{2}$. This was followed by fusion of crystals with a $\mathrm{CO}_{2}$ laser, mass spectrometry, mass discrimination corrections, nucleogenic reactor corrections, and error propagation (see Smith and others, 2003). The mean age was weighted by the inverse variance of each measurement and is reported at the $2 \sigma$ level (Appendix B). Uncertainty in the neutron fluence parameter $J$ was 0.1 percent, based on 39 measurements of Taylor Creek Rhyolite sanidine standard crystals (TCs; Duffield and Dalrymple, 1990). This uncertainty was propagated into the final age. The age used for TCs is $28.34 \pm 0.28$ Ma relative to $98.79 \pm 0.96 \mathrm{Ma}$ for the primary standard GA-1550 biotite (McDougall and Roksandic, 1974; Renne and others, 1998), which is intercalibrated to $28.02 \pm 0.28 \mathrm{Ma}$ for the Fish Canyon Tuff sanidine.

Twenty three laser-fusion analyses on multi-crystal (20) aliquots of optically clear sanidine yielded a weighted mean apparent age of $59.00 \pm 0.30 \mathrm{Ma}$ (fig. 4 and Appendix B). Single-crystal analyses were not possible because of small crystal size. The analyses define an isochron of $59.11 \pm 0.34$ Ma with an ${ }^{40} \mathrm{Ar} /{ }^{36} \mathrm{Ar}$ intercept of $290.9 \pm$ 6.8 (fig. 4), which is consistent with an atmospheric trapped component. Because 

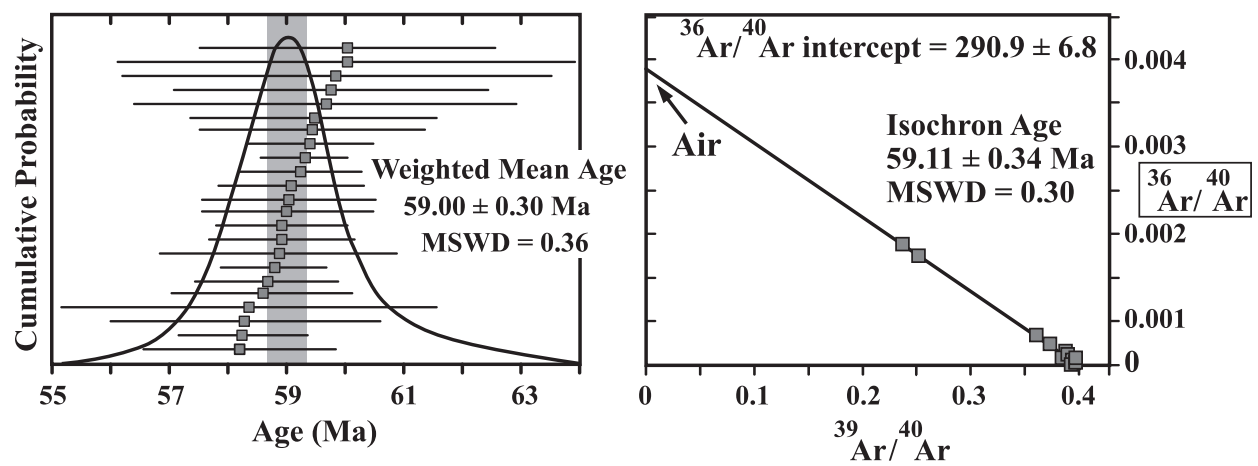

Fig. 4. Cumulative probability (left) and inverse isochron (right) diagrams of 23 laser-fusion ${ }^{40} \mathrm{Ar} /{ }^{39} \mathrm{Ar}$ ages for sanidine from Belt Ash. Ages are relative to 28.34 Ma for Taylor Creek Sanidine (McDougall and Roksandic, 1974; Renne and others, 1998). Individual age determinations, weighted mean, and isochron age are shown with $\pm 2 \sigma$ analytical uncertainties. MSWD $=$ Mean squared weighted deviation.

there is no evidence of excess or inherited argon, the weighted mean apparent age provides the best estimate of time elapsed since eruption and deposition of the ash. When compared to the GPTS, or other ages acquired using ${ }^{40} \mathrm{Ar} /{ }^{39} \mathrm{Ar}$ standards other than TCs, an additional 0.04 myr of uncertainty is added to the overall age calculation (Appendix B).

The small size of sanidine crystals in the Belt Ash $(75-125 \mu \mathrm{m})$ necessitated multi-crystal analysis. Multiple-crystal ages can exhibit a lower apparent spread than single-crystal ages, however, and lead to underestimated error (Smith and others, 2004). They may also mask the incorporation of xenocrysts during eruption and can result in older mean ages. Nevertheless, there is no evidence for bimodality in our radioisotopic data. Greater error is positively correlated with older ages (fig. 4), but this is probably due to the "edge effect" whereby aliquots with lower precision tend to fall near the extremes of variance. Lower precision is correlated with smaller gas yield, probably due to smaller crystal size. Although the possibility of xenocrystic contamination cannot be eliminated with complete certainty, a mean squared weighted deviation (MSWD) greater than 0.36 (Appendix B) might be expected if contaminants were present.

\section{BELT ASH AND THE GPTS}

The weighted mean age of the Belt Ash, 59.00 \pm 0.30 Ma (fig. 4), falls within polarity Chron C26r using either GPTS-95 or GPTS-04 (fig. 5). This confirms that the reversed polarity zone on Polecat Bench containing the ash was correctly correlated to C26r by Butler and others (1981, fig. 10). We compare the radioisotopic age of the ash to predicted ages based on stratigraphic position (fig. 5). Predicted ages were calculated using a cubic spline function (a smoothed line comprised of a series of third-order polynomials) fit through polarity zone boundaries on Polecat Bench, calibrated separately to GPTS-95 and GPTS-04 (table 1, figs. 5 and 6). Because a hiatus may occur near the base of polarity zone C26r, as discussed above, ages for the ash were calculated with and without hiatuses of 0.5 and 1.0 myr. All interpolated ages for the ash using GPTS-04 are indistinguishable from the radioisotopic age (fig. 5B). In contrast, interpolated ages using GPTS-95 fall outside the envelope of uncertainty of the radioisotopic age (fig. 5A). Our results corroborate the revised age for the C26r-C26n Chron reversal in GPTS-04.

\section{MAGNETOSTRATIGRAPHY}

Paleomagnetic samples were collected from stratigraphic sections on the west side of Polecat Bench (fig. 1, upper left, PQ section) and in Foster Gulch (see below) to 
A. GPTS-95

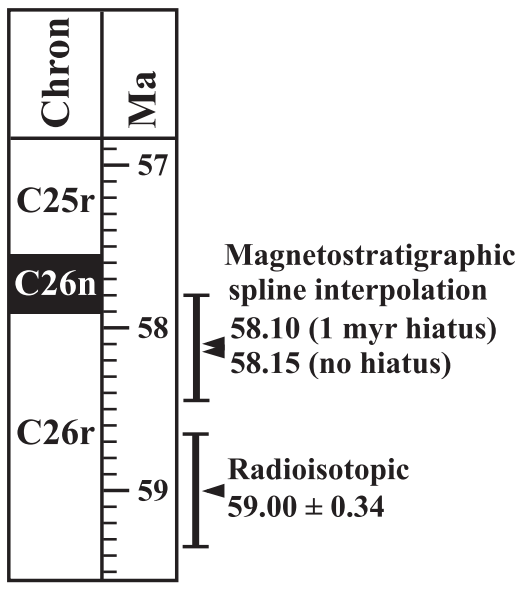

B. GPTS-04

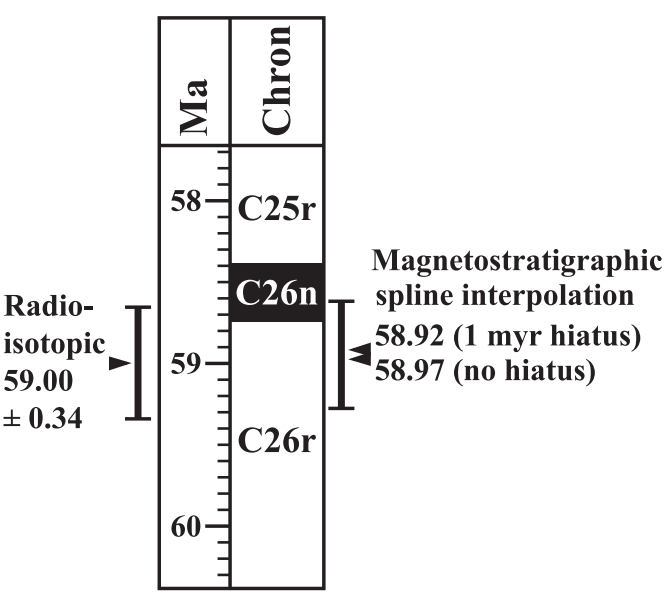

Fig. 5. Comparison of radioisotopic age of Belt Ash with magnetostratigraphic age estimates calibrated to: (A) GPTS-95 (Cande and Kent, 1992, 1995) and (B) GPTS-04 (Ogg and Smith, 2004). Vertical bars show analytical and intercalibration uncertainty of \pm 0.34 myr for radioisotopic age, and assumed uncertainty of \pm 0.30 myr for magnetostratigraphic spline estimates. Latter uncertainty is a function of both GPTS and stratigraphic uncertainty, but because the Belt Ash is in close proximity to base of polarity zone C26n, stratigraphic uncertainty is small. Younger spline estimates assume a 1 myr hiatus at base of polarity zone C26r in Polecat Bench section. Note close agreement of radioisotopic and magnetostratigraphic estimates using GPTS-04 calibration (B).

correlate key fossil localities to the main section on the southeast side of Polecat Bench (fig. 2). Three or more oriented samples were collected from a total of 49 discrete sites in measured stratigraphic sections and analyzed in the paleomagnetism laboratory at the University of New Hampshire. Previous paleomagnetic studies in the northern Bighorn and Crazy Mountains basins found that stepwise alternating field (AF) demagnetization up to peak fields of $100 \mathrm{mT}$ is the most effective protocol for isolating the characteristic remanence magnetization in siltstones of the Fort Union Formation (Butler and others, 1981, pp. 302, 1987, 652-653). Our results corroborate this finding.

Characteristic directions for samples that exhibited linear decay to the origin $(47 \%)$ were computed using least-squares analysis whereas directions for samples that showed strong clustering of vector end points but no linear decay to the origin $(21 \%)$ were calculated using a Fisher mean (figs. 7A and 7B). In some samples (14\%), the overlapping unblocking spectra of the magnetic components obscured any linear demagnetization trends and the progression of remanence directions along a great circle path from the overprinting direction to a reversed polarity was used to determine the characteristic direction (fig. 7C). The rest of the samples (18\%) exhibited unstable demagnetization behavior and could not be used to determine polarity.

Summary statistics were calculated for those sites that contained three or more samples exhibiting stable demagnetization (Appendix C). Alpha sites were those in which all samples were characterized by a line or mean direction and exhibited clustering that passed the Watson test for randomness (Watson, 1956). Beta sites were those in which all three samples exhibited consistent polarities, but one or more samples were characterized by a great circle direction. Individual samples that were not included in alpha or beta sites, but were still characterized by stable demagnetization, were also considered when determining the placement of polarity boundaries.

Mean characteristic directions from alpha sites show better clustering in stratigraphic coordinates (100\% tilt correction) than geographic coordinates and pass the fold test at the 95 percent confidence level (fig. 7D) (Tauxe and Watson, 1994). 
TABLE 1

Stratigraphic levels and age calibrations for biozone and polarity zone boundaries from sections on the southeastern (SPB) and western (WPB) sides of Polecat Bench (figs. 1 and 2). All data for base of zone. Biozone and ash calibrations from cubic spline interpolation (CSI, fig. 6). Polarity chron and CIE ages from GPTS-04 (Ogg and Smith, 2004); Hiatuses of 0.5 and 1.0 myr modeled at base of C26r. Accum. = accumulation; Diff. $=$ difference; $m=$ meters; myr $=$ million years; $N H=$ no hiatus

\begin{tabular}{lccccccc}
\hline $\begin{array}{c}\text { Biozone } \\
\text { or } \\
\text { feature }\end{array}$ & $\begin{array}{c}\text { SPB } \\
\text { (m) }\end{array}$ & $\begin{array}{c}\text { WPB } \\
\text { (m) }\end{array}$ & $\begin{array}{c}\text { CSI } \\
\text { hotus } \\
\text { Ma }\end{array}$ & $\begin{array}{c}\text { CSI } \\
\mathbf{0 . 5} \\
\text { hiatus } \\
\text { Ma }\end{array}$ & $\begin{array}{c}\text { Diff. } \\
\text { myr }\end{array}$ & $\begin{array}{c}\text { CSI } \\
\text { hiatus } \\
\text { Ma }\end{array}$ & $\begin{array}{c}\text { Diff. } \\
\text { myr }\end{array}$ \\
\hline CIE & 1475 & $0^{*}$ & -55.80 & -55.80 & 0.00 & -55.80 & 0.00 \\
Cf-3 & 1290 & $-190^{*}$ & -56.22 & -56.22 & 0.00 & -56.22 & 0.00 \\
Cf-2 & 1150 & $-340^{*}$ & -56.50 & -56.50 & 0.00 & -56.50 & 0.00 \\
Cf-1 & 866 & 432 & -56.99 & -56.99 & 0.00 & -56.99 & 0.00 \\
Ti-6 & 736 & 305 & -57.34 & -57.34 & 0.00 & -57.34 & 0.01 \\
Ti-5b & 640 & 215 & -57.69 & -57.69 & 0.01 & -57.68 & 0.02 \\
Ti-5a & 489 & 102 & -58.31 & -58.31 & 0.00 & -58.31 & 0.01 \\
Ti-4b & 350 & & -58.85 & -58.84 & 0.01 & -58.83 & 0.02 \\
Belt Ash & 331 & & -58.97 & -58.95 & 0.02 & -58.92 & 0.05 \\
Ti-4a & 265 & & -59.50 & -59.39 & 0.11 & -59.29 & 0.21 \\
Ti-3 & 194 & & -60.29 & -60.04 & 0.24 & -59.80 & 0.49 \\
Ti-2 & 139 & & -60.95 & -60.58 & 0.37 & -60.21 & 0.73 \\
To-Ti & 89 & & -61.57 & -61.09 & 0.49 & -60.60 & 0.97 \\
\hline
\end{tabular}

\begin{tabular}{|c|c|c|c|c|c|}
\hline $\begin{array}{c}\text { Polarity } \\
\text { Zone } \\
\end{array}$ & $\begin{array}{c}\text { Polarity } \\
\text { zone } \\
\text { SPB } \\
(\mathrm{m}) \\
\end{array}$ & $\begin{array}{c}\text { Polarity } \\
\text { Chron } \\
\text { SPB } \\
\text { Ma } \\
\end{array}$ & $\begin{array}{c}\text { Polarity } \\
\text { Zone } \\
\text { WPB } \\
\text { (m) } \\
\end{array}$ & $\begin{array}{c}\text { Mean } \\
\text { Accum. } \\
\text { rates } \\
\text { linear }(\mathbf{N H}) \\
\mathbf{m} / \mathbf{m y r} \\
\end{array}$ & $\begin{array}{c}\text { Mean } \\
\text { Accum. } \\
\text { rates } \\
\text { spline }(\mathbf{N H}) \\
\text { m/myr } \\
\end{array}$ \\
\hline C24R & 1058 & -56.665 & & 482 & 487 \\
\hline $\mathrm{C} 25 \mathrm{~N}$ & 789 & -57.180 & 355 & 522 & 546 \\
\hline C25R & 470 & -58.379 & 56 & 266 & 268 \\
\hline $\mathrm{C} 26 \mathrm{~N}$ & 370 & -58.737 & & 279 & 287 \\
\hline C26R & 83 & -61.650 & & 99 & 105 \\
\hline
\end{tabular}

$*=$ level measured down from CIE.

Although the mean characteristic directions for the alpha sites also appear antipodal, they do not pass the reversal test at the 95 percent confidence level due to shallower reversed directions compared to normal directions. This is likely due to incomplete removal of a present-day normal overprint. The overall mean characteristic direction (Dec/Inc) for the alpha sites is $351 / 53\left(\alpha_{95}=6.8\right)$. This agrees well with the expected 


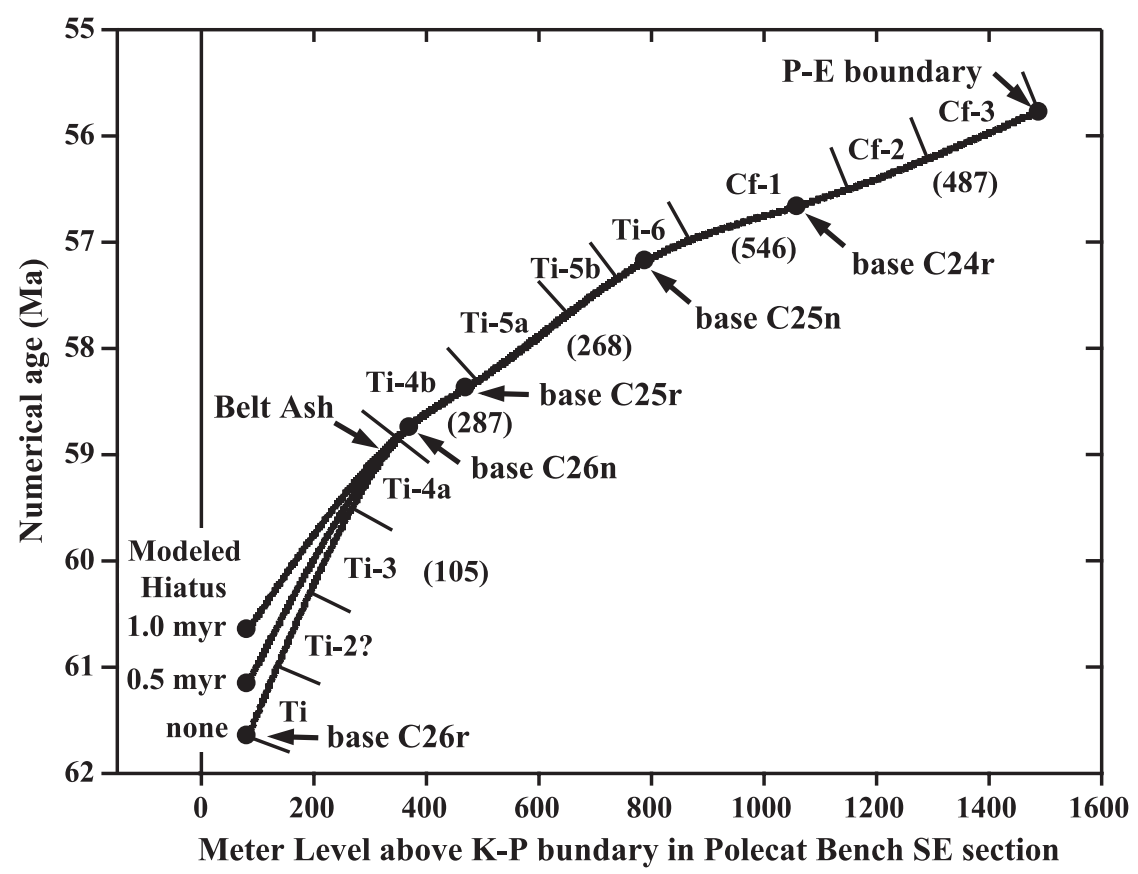

Fig. 6. Cubic spline function used to calibrate biozone boundaries and magnetostratigraphic age for Belt Ash (table 1). Three curves at lower left were modeled with hiatuses of $0,0.5$, and 1.0 myr at base of polarity zone C26r on Polecat Bench (table 1). Anchor points (solid circles) are polarity chron and P-E boundary (base of CIE) ages from GPTS-04. Bars perpendicular to spline curve indicate position of Tiffanian (Ti) and Clarkforkian (Cf) biozone boundaries. Mean accumulation rates (m/myr) from spline estimates for intervals between anchor points shown in parentheses. Spline curves were generated with PetroPlot freeware (Su, Y., Langmuir, C. H., and Asimow, P. D., 1999-2002).

direction of 349/63 $\left(\alpha_{95}=2.6\right)$ for the early Eocene of the Bighorn Basin, based on the Eocene reference pole for North America (Diehl and others, 1983), and it is significantly different from the present-day geocentric axial dipole field direction for this location of $0 / 63$.

\section{Princeton Quarry Section-West Polecat Bench}

We sampled a $170 \mathrm{~m}$ section below Princeton Quarry in order to extend downward the "Polecat Bench Northwest" paleomagnetic section of Butler and others (1981, figs. 1 and 5) and to better constrain the geochronology of many important late Paleocene fossil localities in this area. Twenty-one sites were sampled in our Princeton Quarry section and after analysis, 13 of these were alpha or beta sites (Appendix C). The lower $55 \mathrm{~m}$ of the Princeton Quarry section are characterized by normal polarity whereas the upper $115 \mathrm{~m}$ are characterized by reversed polarity (fig. 8A). The polarity transition at the $55 \mathrm{~m}$ level in the Princeton Quarry section undoubtedly represents the Chron C26n-C25r boundary based on its stratigraphic position relative to the C25rC25n boundary, which occurs about $300 \mathrm{~m}$ higher on this side of Polecat Bench (fig. 2). The stratigraphic thickness between these boundaries on the southeastern side of Polecat Bench is nearly the same $(320 \mathrm{~m}$, fig. 2). Correlation of the normal zone above the Princeton Quarry section to Chron C25n in the GPTS by Butler and others (1981, fig. 10) is strongly supported by its position relative to the Paleocene-Eocene boundary and the CIE (Koch and others, 1992, 1995; Clyde, ms, 1997; Gingerich, 2001, 2003; Magioncalda and others, 2004). The lowest site in the Princeton Quarry section is characterized by normal polarity, so there is no evidence that the top of Chron C26r is present in this section. 
A. N, Up BH0434A

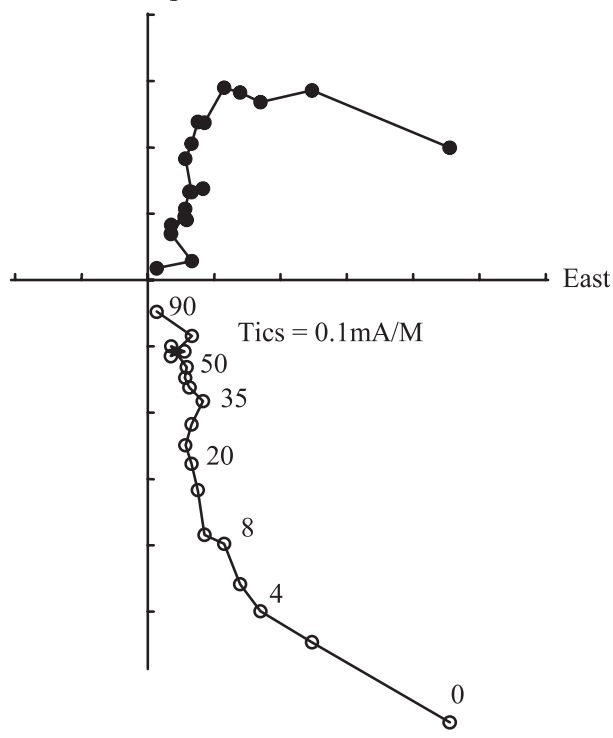

B. N, Up BH0452D

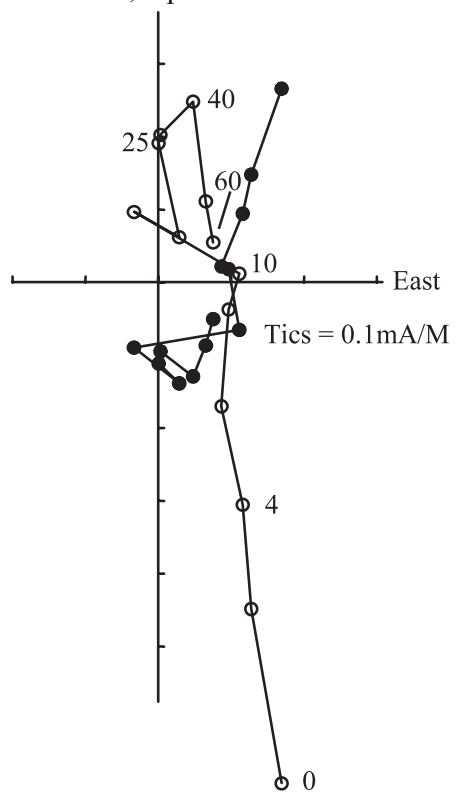

C.

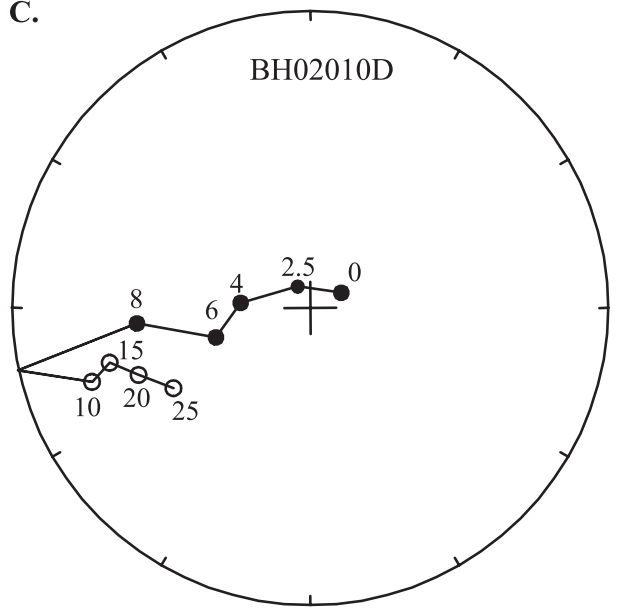

D.

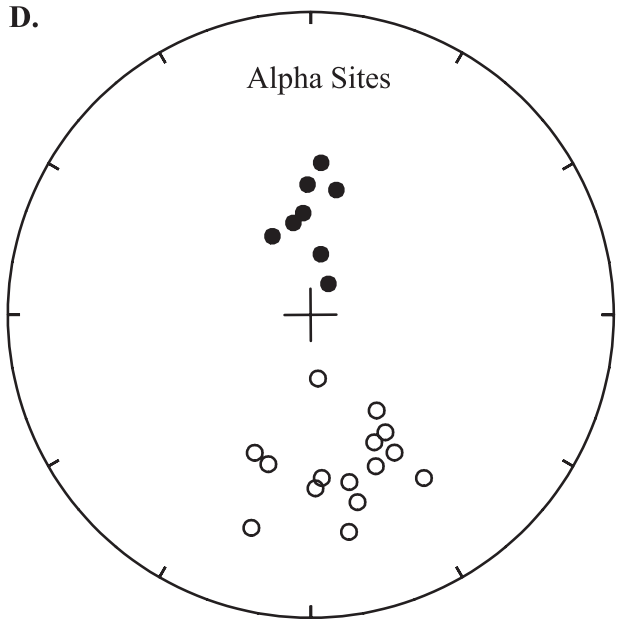

Fig. 7. Paleomagnetic results from this study. (A) and (B) are vector endpoint diagrams (Zijderveld, 1967) where open symbols show vector endpoints in vertical plane and closed symbols in horizontal. (A) Sample exhibiting linear demagnetization to the origin whose characteristic direction was determined by least-squares linear regression analysis, and (B) a sample exhibiting clustering of vector end points during demagnetization whose characteristic direction was determined by a Fisher mean. (C) and (D) are equal area projections where open symbols lie on upper and closed symbols on lower hemisphere of projection. (C) Sample exhibiting progression of remanence directions along a great circle path during demagnetization. (D) Mean characteristic directions of alpha sites. All directions are in stratigraphic coordinates and the demagnetizing field in $\mathrm{mT}$ is shown next to vector end-points.

\section{Foster Gulch}

Twenty-eight paleomagnetic sites were sampled from the Foster Gulch area, which lies $\sim 40 \mathrm{~km}$ to the southeast of Polecat Bench (see Appendix A for discussion of Foster Gulch quarries). These sites were tied together via lithostratigraphic correlation of marker beds and referenced to the composite stratigraphic section of Clyde (ms, 1997, 
A.

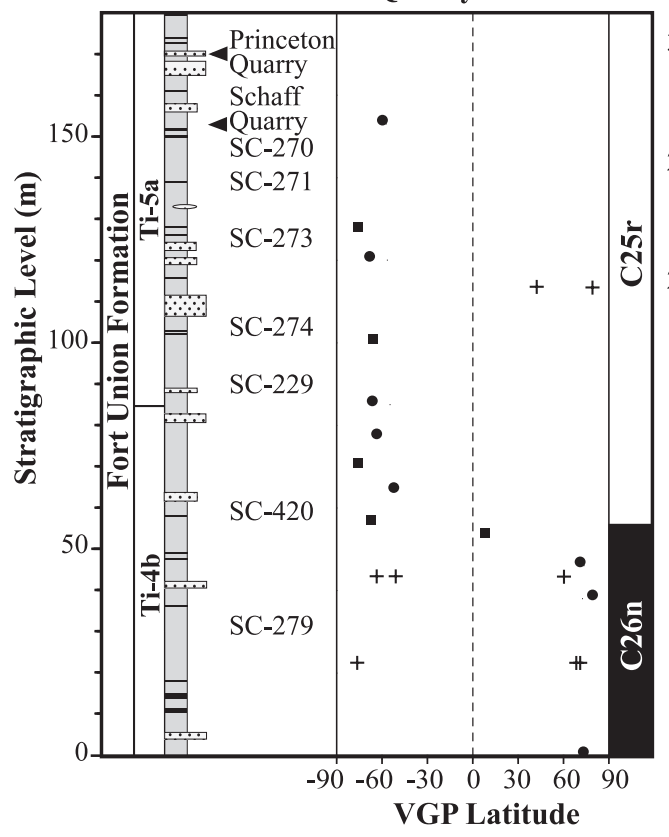

B.

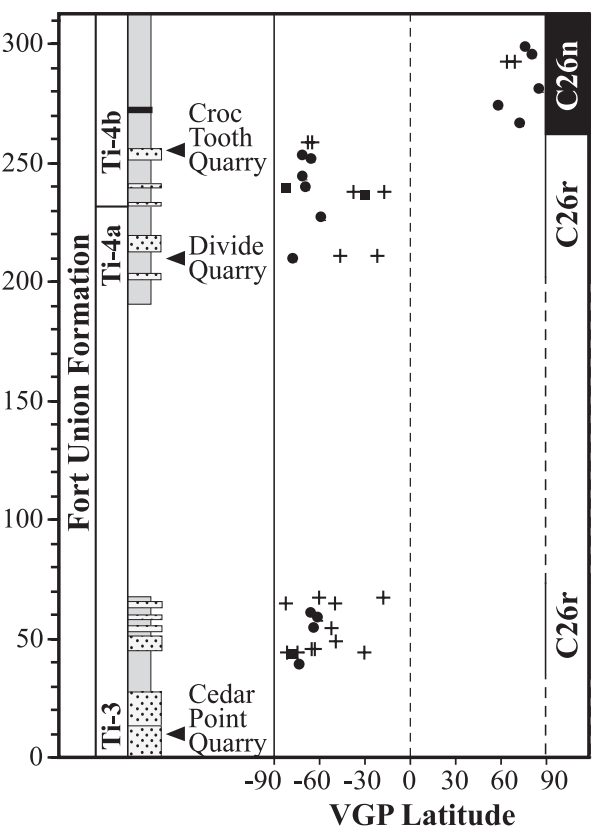

Fig. 8. Summary of magnetostratigraphic data from (A) Princeton Quarry and (B) Foster Gulch sections. Lithology and biozone symbols are shown at left of each diagram as well as stratigraphic position of fossil localities. Solid circles represent mean VGP latitude of alpha sites, solid squares mean VGP latitude of beta sites, and crosses VGP latitude of samples not included in site statistics (see text for description of alpha and beta sites). Interpreted polarity pattern and GPTS Chron assignments are shown at right.

Appendix B; 2001, pp. 115-117). The lowest 11 sites were sampled from beds directly above Cedar Point Quarry (P. rex biozone, Ti-3) whereas the remaining 17 sites were sampled from beds that stratigraphically encompass Divide and Croc Tooth quarries (P. churchilli $[\mathrm{Ti}-4 \mathrm{a}]$, and Phenacolemur $[\mathrm{Ti}-4 \mathrm{~b}]$ biozones, respectively). Results indicate that all three quarries are associated with sites of reversed polarity and that there is a change to normal polarity about 5 meters above Croc Tooth Quarry, which is the highest quarry in the composite section ( $\sim 260$ meter level; fig. $8 \mathrm{~B})$. This polarity reversal must represent the Chron C26r-C26n boundary based on its expected position relative to biostratigraphic tie points. Assignment of this reversal to any other chron boundary would imply great biostratigraphic diachrony ( $\geq 1.5 \mathrm{myr}$ ) between Foster Gulch and Polecat Bench. Previous correlation between these areas was based on the assumed biostratigraphic equivalence of Croc Tooth Quarry in Foster Gulch and SC-243 on Polecat Bench (Secord, ms, 2004, p. 25). The data presented here indicate that these localities occur approximately 5 and $20 \mathrm{~m}$ below the base of C26n, respectively, indicating a high degree of consistency between the paleomagnetic and biostratigraphic data.

The location of the C26r-C26n boundary in Foster Gulch provides an important tie point to Polecat Bench and to the GPTS, and greatly strengthens the chronostratigraphic framework of the northern Bighorn Basin. Our new paleomagnetic results from Foster Gulch corroborate our biostratigraphic data from Polecat Bench that place the $P$. churchilli zone entirely in Chron C26r. This is significant because placement of the $P$. churchilli zone in Foster Gulch is based on much larger fossil samples (see Appendix A). The recognition that Ti-4a lies in C26r, rather than C25r, has important implications for the age of the Mason Pocket fauna in the type Tiffanian 
of southern Colorado (see "Correlation of Type Tiffanian to Polecat Bench" section in text below).

TIFFANIAN AND CLARKFORKIAN LAND-MAMMAL AGES

North American land-mammal ages were first established by the Wood Committee (Wood and others, 1941) as "provincial ages." Because many mammalian faunas occurred in isolated outcrops and their superpositional relationships to other faunas were not clear, the Wood Committee based land-mammal ages primarily on faunal content. Type areas were assigned to each land-mammal age, but neither type stratigraphic sections nor meter levels were specified. These provincial ages were not true geochronologic ages, because they were not based on described fossil sequences in discrete stratigraphic sections, and thus they lacked defining chronostratigraphic stages (see NACSN, 2005). The faunal content and temporal extent of many landmammal ages is now better known. Some, such as the Clarkforkian, can now be considered valid geochronologic units. Others, such as the Tiffanian, are more problematic.

The Tiffanian was initially based on the "Tiffany beds" (now part of the Animas Formation) in the northern San Juan Basin of southwestern Colorado and was typified by the Mason Pocket local fauna (see below). The Tiffanian is currently defined as the temporal interval between the first appearance of Plesiadapis and the first appearance of Rodentia (Lofgren and others, 2004), which we follow here. As noted above, neither the lower nor upper boundary of the Tiffanian has been recognized in the type area, but the former is constrained by faunas in the Hanna Basin (Higgins, 2003) and the latter by faunas in the Bighorn Basin (Rose, 1980, 1981; Gingerich, 2001). The Bighorn Basin contains the most complete and most studied continuous record of middle and late Tiffanian faunas (Ti-3 to Ti-6). The stratigraphic ranges shown in figure 9 define the composition of this interval, and the Polecat Bench sequence can now be viewed as the stratotype for the middle and late Tiffanian. Although it would be appropriate to abandon the term "Tiffanian" and apply a local geographic name to this stratigraphic interval, use of the term is widespread, and we follow historical precedent.

The Clarkforkian land-mammal age is based on stratigraphic sequences in the Clarks Fork Basin, a northwestern sub-basin of the Bighorn Basin in northern Wyoming and southern Montana that includes Polecat Bench (Gingerich, 1983a, fig. 1). The Clarkforkian is currently recognized as the interval between the first appearance of Rodentia and the first appearance of Artiodactyla (Lofgren and others, 2004). The first artiodactyls appear early in the CIE, along with perissodactyls and primates, not far above the P-E boundary, and mark the beginning of the Wasatchian land-mammal age (Gingerich and Clyde, 2001; Magioncalda and others, 2004). The earliest known occurrence of rodents in North America is in the Bighorn Basin, which contains the only known detailed record of faunas across the Tiffanian-Clarkforkian (Ti-Cf) boundary. The recent discovery of a rodent molar (UM 108587) in a freshwater limestone has shifted the Ti-Cf boundary down $35 \mathrm{~m}(\sim 0.07$ myr earlier) to UM locality SC-181 on the west side of Polecat Bench (fig. 2, right column). The boundary was previously placed at nearby locality SC-179 (Rose, 1981; Gingerich, 2001). At least two rodent species are present at SC-179, a large species (probably Acritoparamys atavus, see Secord, ms, 2004, pp. 156-158) and an undescribed smaller species (see Bloch, ms, 2001, pp. 111-112).

The Ti-Cf boundary is formally based on the first occurrence of rodents, but several authors have reported that it can also be recognized by the first appearance of tillodonts (Esthonyx), Haplomylus, and Coryphodon (for example, Rose, 1981, p. 12; Archibald and others, 1987, p. 61; Lofgren and others, 2004, p. 85), which are also thought to have been intercontinental immigrants. SC-179 and SC-362 are the lowest Clarkforkian localities that have yielded relatively large fossil samples (136 cataloged specimens) and are about $35 \mathrm{~m}$ above the first occurrence of rodents (fig. 2, right 


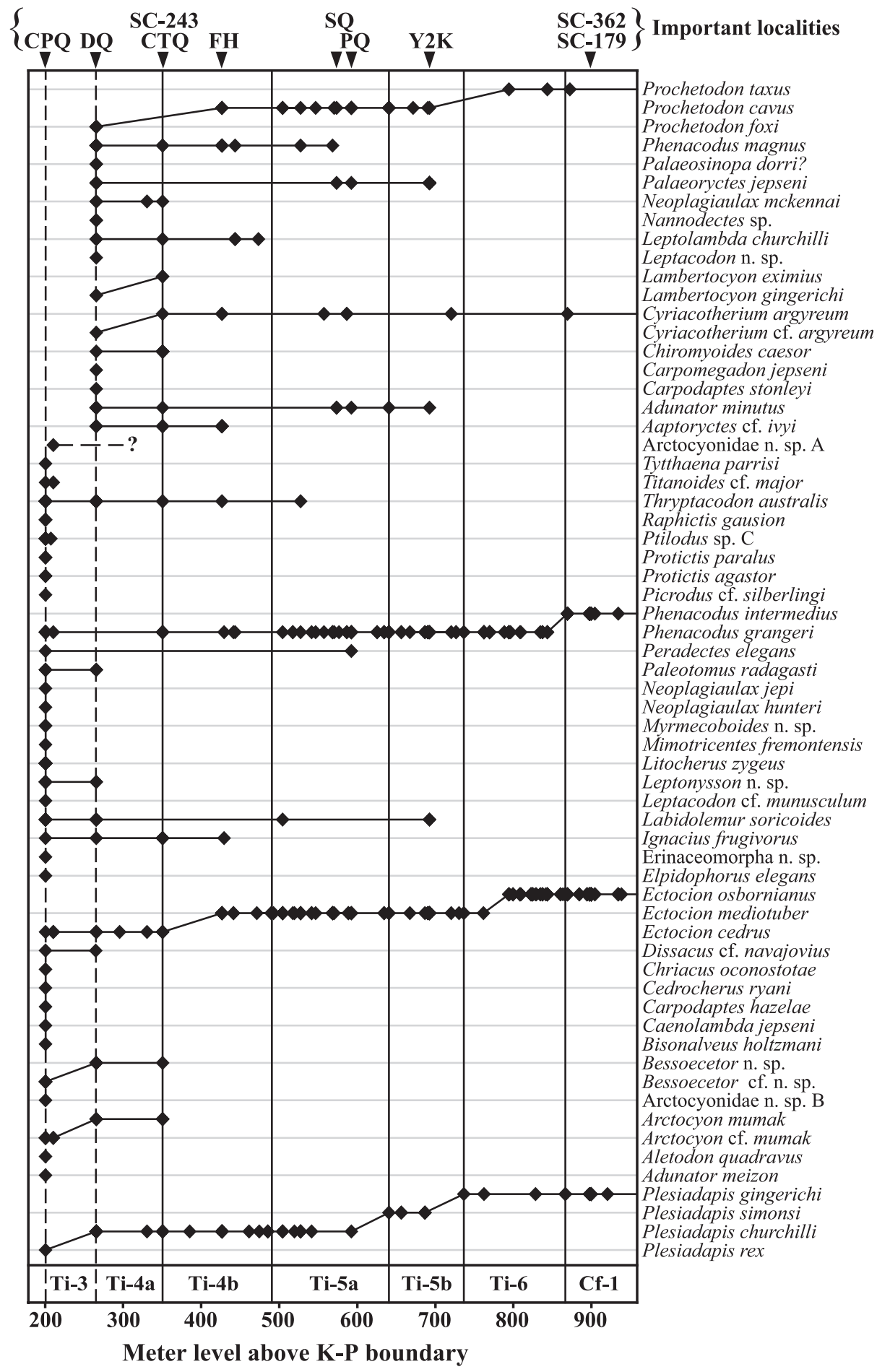

Fig. 9. Chart showing stratigraphic occurrences of 126 species or conferred species (cf.) from Tiffanian and early Clarkforkian localities on Polecat Bench, in Sand Coulee, and from Cedar Point (CPQ), Divide (DQ), and Croc Tooth (CTQ) quarries in the Foster Gulch area (fig. 8B and Appendix A). Data compiled from sections in figure 2, normalizing meter levels between top of C26n and base of C25n. Bear Creek fauna in southern Montana is not shown but includes additional early Clarkforkian (Cf-1) first occurrences of 


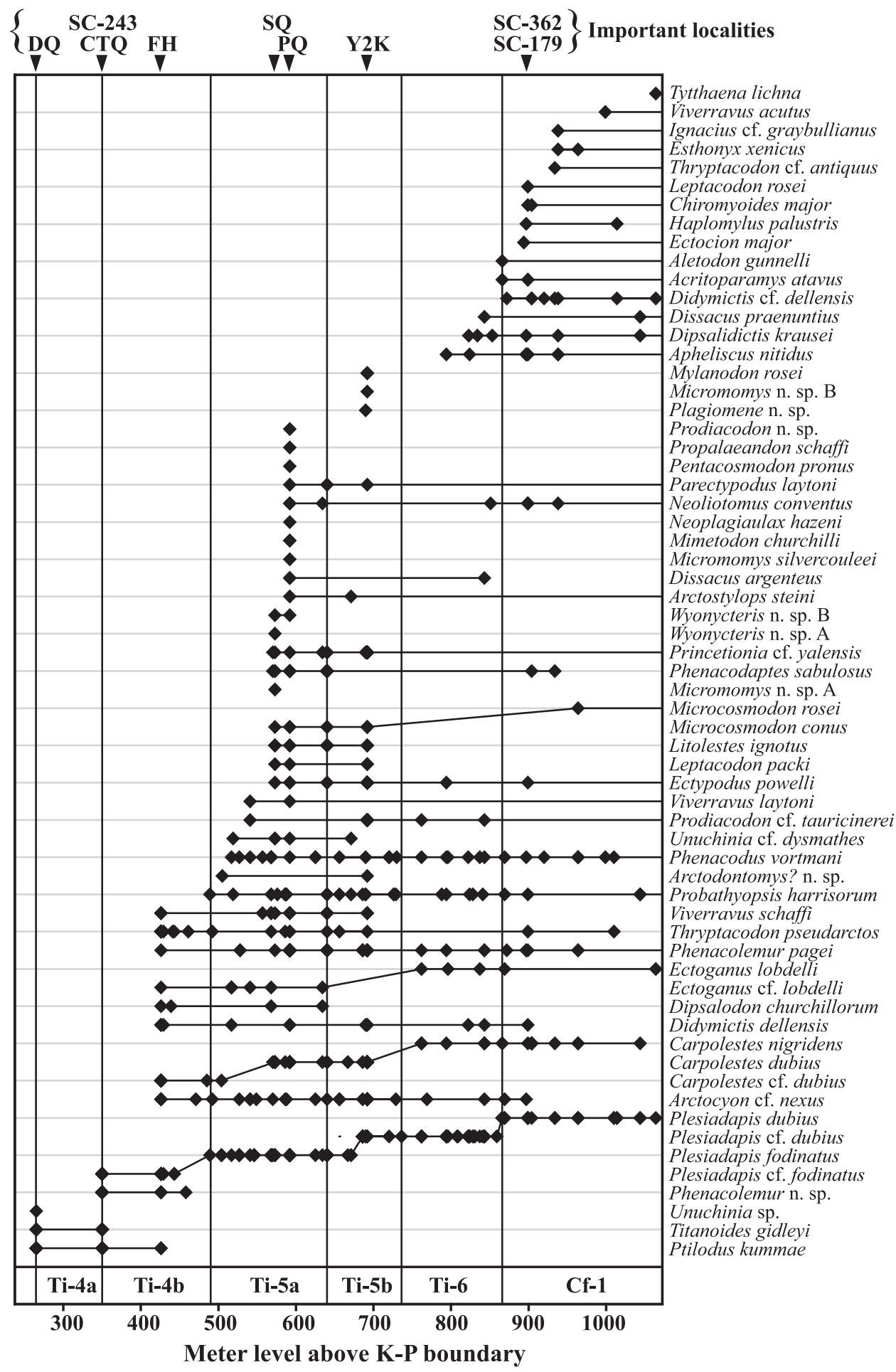

Labidolemurkayi and Leipsanolestes (L. siegfriedti). Planetetherium mirabile and Protentomodon ursirivalis are known with certainty only from Bear Creek (Simpson, 1928, 1929a, 1929b; Gunnell and Bartels, 2001). Biozone abbreviations as in figure 3. Connected lines show species in presumed evolutionary lineages. Additional quarries: $\mathrm{PQ}=$ Princeton; $\mathrm{SQ}=$ Schaff; Y2K. FH = Fossil Hollow (SC-198). See Secord (ms, 2004) for description and discussion of Tiffanian species. 
column). Haplomylus was recently documented at this level (Secord, ms, 2004, pp. 295-296) but not Esthonyx or Coryphodon. Esthonyx is known from SC-83, which is $\sim 40 \mathrm{~m}$ higher (fig. 2, left column), and its absence at lower levels could reasonably be a sampling artifact. Coryphodon, however, which is the largest known Paleocene mammal and is not easily overlooked by collectors, is not known with certainty until the middle Clarkforkian (Cf-2). Once Coryphodon does appear with certainty, about $325 \mathrm{~m}$ above the Ti-Cf boundary (SC-108), it quickly becomes common. The only specimen from Cf-1 that may belong to Coryphodon is a fragment of an upper canine (UM 71575) from SC-83 (fig. 2, left column), which has the morphology of Coryphodon, but could also be from a different pantodont. Collections from Cf-1 in the Bighorn Basin are relatively small and larger samples are needed to confidently determine if Coryphodon is present. Even if it is found to be present, however, it appears to be a rare genus until Cf-2 and should not be used independently to recognize the Ti-Cf boundary.

The synchrony of the Ti-Cf boundary and other Paleocene biozone boundaries has not been tested outside the Bighorn Basin, but the chronostratigraphic framework presented here will help to facilitate such work and to better constrain the timing of immigration events.

\section{REVISED BIOSTRATIGRAPHY}

Taxa used to define new zone boundaries were chosen for their identifiability, geographic distribution, and abundance in the fossil record. In all cases we used the first occurrence of a single taxon to define a boundary. Some authors have recommended the use of multiple taxa to define boundaries (for example, Savage and Russell, 1977, pp. 51-52). Although such boundaries may be more stable than singletaxon boundaries, they are inherently less precise, except in rare instances when multiple taxa appear simultaneously (for example, Gingerich, 1989, 2001). Some biostratigraphers prefer to use immigrant taxa to define zone boundaries (Repenning, 1967; Woodburne, 1977), as we have done for the Probathyopsis zone (Ti-5a). Immigrant taxa are often easily distinguished from native taxa because close relatives are not present in the contemporary fauna. It is clear from modern examples that immigrant taxa can disperse rapidly and thus provide boundaries that are virtually synchronous in the geologic record. Although we have defined boundaries using single taxa, we do not recommend the sole use of the boundary-defining taxon for purposes of regional correlation. Rather, we advocate the use of all available biostratigraphic and geochronologic data (see "Correlation of Type Tiffanian to Polecat Bench" section). In instances of great biostratigraphic complexity, computational algorithms may provide the most reliable correlations (Alroy, 1994, 2000; Webster and others, 2003).

Biozonation for most of the late Paleocene was traditionally based on evolutionary lineages of Plesiadapis (for example, Gingerich, 1975, 1976, 1983a, 2001). Plesiadapis has the advantage of being a common genus in many Tiffanian and Clarkforkian localities with a well-documented evolutionary history. However, because species of Plesiadapis are segments in a morphologic continuum (Gingerich, 1976), the placement of zone boundaries is somewhat arbitrary. Additionally, confident identification of species can be difficult without large samples or unusually complete dental material. For these reasons we have chosen to define new biozones based on the first occurrences of taxa that are not closely related to those that define the preceding or succeeding zones (interval zones of ISSC, 1994, pp. 59-61; and NACSN, 2005, p. 1574). Boundaries of interval zones have the advantage of being precise, but they can shift significantly with the discovery of the defining taxon at a lower stratigraphic level (for example, see revision of Torrejonian in Lofgren and others, 2004, p. 72). Nevertheless, with intensive sampling, interval zones should provide less ambiguous boundaries than lineage zones. 
Figure 3 compares differences between the biostratigraphic revision presented here and the most recent biostratigraphy for the northern Bighorn Basin by Gingerich (2001, table 1). Our revision includes the addition of three new biozones, the Phenacolemur interval zone (Ti-4b), the Probathyopsis interval zone (Ti-5a), and the Copecion interval zone (Cf-3). Each zone bears the name of the taxon whose first occurrence defines the base. The top is defined by the first occurrence of the succeeding zone-taxon. Formal definitions for the new zones are given in Appendix D and stratigraphic levels in table 1. Figure 9 shows the stratigraphic occurrences of most mammalian species of Tiffanian and early Clarkforkian (Cf-1) age in the northern Bighorn Basin.

The Phenacolemur zone is stratigraphically equivalent to the Plesiadapis churchilli zone of Gingerich (2001, Ti-4, p. 41, fig. 3) (fig. 3). In our revision, however, the $P$. churchilli zone has shifted to a considerably lower stratigraphic level on Polecat Bench, based on taxa from locality SC-261 (see Appendix A). The downward shift is corroborated by recognition of $\mathrm{C} 26 \mathrm{n}$ in the Foster Gulch area above the Ti-4a\Ti-4b boundary, as noted above. The $P$. churchilli zone (Ti-4a) now occupies a stratigraphic interval on Polecat Bench previously in the $P$. rex zone (Ti-3, Gingerich, 2001, p. 41, fig. 3). Phenacolemur $\left(=\right.$ Dillerlemur $\left.^{3}\right)$ is a distinctive taxon, easily distinguished from other plesiadapiforms by its hypertrophied $\mathrm{P}_{4}$ and upper premolars (for example, Bown and Rose, 1976; Rose, 1981). It is known from many late Paleocene localities in Wyoming and Montana (Archibald and others, 1987).

An important event that occurs in the Phenacolemur zone is the last occurrence of the multituberculate Ptilodus (fig. 9, P. kummae). Ptilodus is an abundantly represented genus in most Tiffanian faunas older than Ti- 5 and its demise marks an important datum that may be useful for regional correlation.

The Probathyopsis zone replaces the P. fodinatus zone of Gingerich (Ti-5a, 2001, table 1, fig. 3) (fig. 3). We abandon the P. fodinatus zone because of difficulties distinguishing $P$. fodinatus from the preceding $P$. cf. fodinatus, which occurs in the Phenacolemur zone (fig. 9). Certain characteristics of $P$. fodinatus, such as a more shelf-like talonid on lower premolars, are variably present in $P$. cf. fodinatus (Secord, ms, 2004, pp. 205-208) and if the $P$. fodinatus zone were retained, the lower boundary would be based in part on character frequency. Probathyopsis, on the other hand, is an intercontinental immigrant and the first representative of the order Dinocerata (uintatheres) to appear in North America (Gingerich, 1985; Beard and Dawson, 1999, pp. 699-700). Its teeth are easily distinguished from those of other North American mammals. It is known regionally as far south as Colorado (Patterson, 1939, p. 199; Thewissen and Gingerich, 1987). Probathyopsis has the disadvantage of being less common than Plesiadapis, but it provides a potentially synchronous boundary free of issues related to evolutionary gradation.

The Copecion zone replaces the Phenacodus-Ectocion acme zone of Rose (Cf-3, 1980; 1981) as the youngest Clarkforkian zone. We redefine Cf-3 because phenacodontid abundance can be influenced by taphonomic and local paleoenvironmental biases, and it has limited value for regional correlation. No taxon other than Copecion appears to be suitable for defining the lower boundary of Cf-3 based on first occurrence. Copecion is not common (11 specimens from eight Cf-3 localities; $\sim 1 \%$ of $\sim 1100$ cataloged UM mammal specimens), but its first occurrence provides an objective datum. The underlying Cf-2 biozone is well sampled in the Bighorn Basin (>2000 UM

3. Named by Robinson and Ivy (1994). We follow Silcox and Gunnell (unpublished manuscript, Plesiadapiformes, in Janis, C. M., Gunnell, G. F., and Uhen, M. D., editors, Evolution of Tertiary mammals of North America Vol. 2: marine mammals and smaller terrestrial mammals: Cambridge University Press) in considering Dillerlemura junior synonym of Phenacolemur. 
specimens) and Copecion has not been identified at this level. Thus, the probability is small that Copecion will be discovered in significantly older strata. In instances where the presence of Copecion is uncertain, the Copecion zone can be recognized as the interval between the last occurrence of Plesiadapis cookei and the first occurrence of earliest Eocene (earliest Wasatchian, Wa-0) immigrants (artiodactyls, perissodactyls, or euprimates).

Copecion does not appear to occur in faunas older than Cf-3 outside the Bighorn Basin, although Clarkforkian localities in which it occurs in the Piceance Creek Basin of Colorado have not been assigned to biozones (Thewissen, 1990, pp. 68-69). A middle Tiffanian (Ti-3) occurrence reported by Lofgren and others (2004, table 3.2) may stem from a faunal list for Love Quarry in which Copecion (then Phenacodus) cf. brachypternus was included (McKenna, 1980, p. 327) or could be a typographic error (no Clarkforkian occurrences were listed). The only specimen (AMNH 89689) from Love Quarry in the AMNH online database identified as P. brachypternus was reidentified as Phenacodus matthewi by Thewissen (1990, p. 49), but none was identified as Copecion. Thus, there is no reason to think that Copecion occurs at Love Quarry or in the Tiffanian.

In summary, the results of our revised biostratigraphy are: (1) documentation of the stratigraphic ranges of all species known to occur in the Tiffanian and early Clarkforkian of the northern Bighorn Basin; (2) reevaluation of existing biozone boundaries; (3) addition of the Phenacolemur zone (Ti-4a); and (4) redefinition of the P. fodinatus (Ti-5a) and Phenacodus-Ectocion (Cf-3) biozones, using first occurrences of Probathyopsis (Ti-5a, revised) and Copecion (Cf-3, revised), respectively.

\section{BIOZONE CALIBRATIONS}

Age estimates for biozone boundaries were made by spline interpolation between polarity zone boundaries, and between the base of zone C24r and the P-E boundary (base of the CIE) on Polecat Bench (fig. 6). Stratigraphic level was used to estimate numerical age, following convention (Agterberg, 1988, 1994, 2004; Cande and Kent, 1992; Gradstein and others, 1995). Ages used for polarity zones and the P-E boundary are from GPTS-04. The close agreement between the radioisotopic age of the Belt Ash and that of the Chron C26r-C26n boundary in GPTS-04 (fig. 5B), negates any need to adjust the GPTS or use the ash as a calibration point for the Polecat Bench section.

Figure 6 shows that the greatest change in slope between calibration points occurs between zones C26r and C26n. The steeper slope in C26r is the result of slower accumulation rates, the presence of one or more hiatuses, or both. The Plesiadapis praecursor zone (Ti-1), which would be expected near the base of C26r (Lofgren and others, 2004, fig. 3.2), may be absent on Polecat Bench (see "Biostratigraphic Constraints ..." section above). To determine the effect of this possible hiatus on our age estimations and slope we calculated spline curves with hiatuses of 0.5 and 1.0 myr at the base of C26r (fig. 6). A 1.0 myr hiatus resulted in substantially younger estimates for biozone boundaries below Ti-4a (table 1). Even with this hiatus, however, the slope for C26r remains steeper than in younger intervals. Thus, even a large hiatus does not entirely explain differences in slope, and it is probable that average accumulation rates were slower in the lower part of zone C26r.

Better age control and larger fossil samples are needed in the lower part of C26r before confident age estimates for biozones in this interval can be made.

\section{CORRELATION OF TYPE TIFFANIAN TO POLECAT BENCH}

Evidence reported here indicates that Mason Pocket, the principal fauna from the type Tiffanian in southwestern Colorado ("Tiffany beds" of Granger, 1917), is considerably older than previously determined. Specimens from Mason Pocket and nearby 


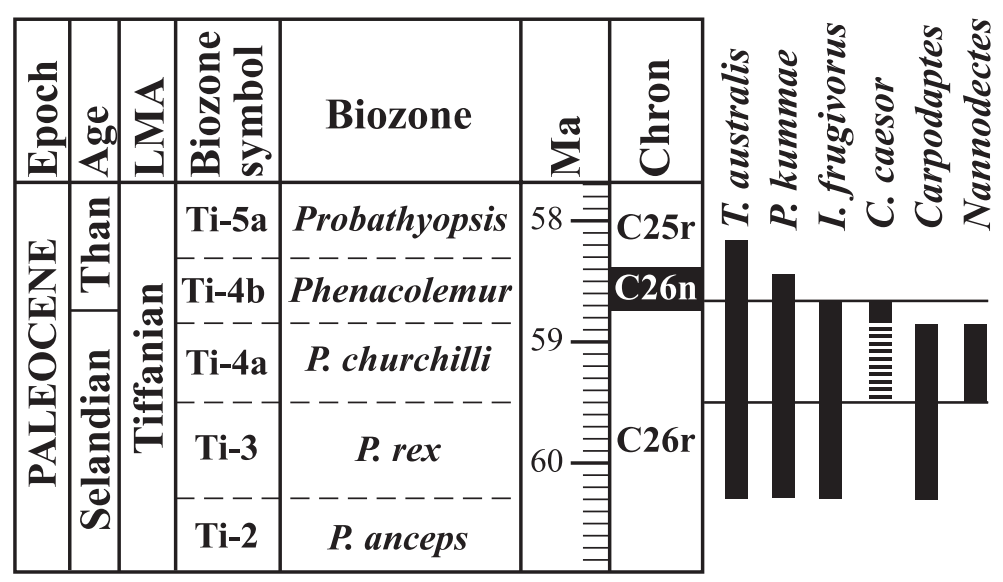

Fig. 10. Geochronologic chart showing the temporal ranges of taxa in the Bighorn Basin known from Mason Pocket in southwestern Colorado. Mason Pocket occurs in an interval of reversed polarity correlated here to Chron C26r. Vertical bars indicate age ranges of taxa in the Bighorn Basin and horizontal bars show probable range of faunal equivalence for Mason Pocket. Peradectes elegans and Labidolemur soricoides are also shared, but they have longer ranges and do not further restrict the age of Mason Pocket. Abbreviations as in fig. 3, or: T. = Thryptacodon; P. = Ptilodus (for bar); I. = Ignacius; C. = Chiromyoides, Than $=$ Thanetian.

localities were described by Granger (1917), Simpson (1935c, 1935b, 1935a), Van Valen (1966, p. 79), Gingerich (1973, 1983b, pp. 251-252), Krause (ms, 1982, p. 173), and Thewissen (1990, p. 55). Butler and others (1981, p. 309) correlated Mason Pocket and overlying beds to polarity zone C25r on Polecat Bench and considered it faunally equivalent to the $P$. churchilli zone (Ti-4, fig. 3, left column). Their correlation was reasonable because Mason Pocket occurs in a zone of reversed polarity and C25r was the only reversed zone that overlapped the range of Ti-4 on Polecat Bench (fig. 3, left column). Their correlation was supported by specimens collected above Mason Pocket that suggested age equivalence to the younger $P$. simonsi zone ( $\sim$ Ti-5a and Ti-5b revised) in the Bighorn Basin. The only reversed polarity zone on Polecat Bench that overlaps with Ti-5 was, and still is, C25r (figs. 2 and 3). Evidence presented here, however, has changed the stratigraphic range of the $P$. churchilli zone, which now extends well below C26n, into C26r (figs. 3 and 9). Thus, reevaluation of the age of the type Tiffanian is in order.

Gingerich (1976, fig. 16) and Butler and others (1981, p. 309) considered Mason Pocket a correlative of the $P$. churchilli zone (Ti-4) based on the presence of Chiromyoides caesor and Nannodectes gidleyi. Data presented here support correlation to Ti-4 (a or lower part of b). Figure 10 illustrates the ranges of biostratigraphically useful taxa from Mason Pocket also known in the Bighorn Basin. Ptilodus kummae, Ignacius frugivorus, Chiromyoides caesor, Carpodaptes, and Nannodectes all restrict the younger age range of Mason Pocket to the older part of Ti-4b or earlier. As noted above, Ptilodus is a common and abundant form in Tiffanian faunas and its last occurrence, represented by $P$. kummae, marks an important biostratigraphic datum. Thryptacodon australis is a relatively common species in zones below Ti-5a and also suggests an earlier age, but it is known from a single specimen (UM 110281) from the earliest part of Ti-5a on Polecat Bench. Carpodaptes and Nannodectes suggest an age older than Ti-4b. Chiromyoides caesor restricts the older age range of Mason Pocket to Ti-4a or younger. Chiromyoides caesor is not known with certainty from Ti-4a, but based on size, a partial $\mathrm{M}_{3}$ (YPM-PU 25014) from Long Draw Quarry (Ti-4a) probably belongs to this species (Secord, ms, 2004, p. 216). Nannodectes does not range below Ti-4a in the Bighorn Basin, but it is well known 
from older faunas south of the Bighorn Basin (Gingerich, 1976); it does not help to constrain the older age range. When the ranges of all taxa are considered, Mason Pocket appears to be faunally equivalent to Ti-4a or the older part of Ti-4b (fig. 10). The absence of Phenacolemur is consistent with a Ti-4a age. These range restrictions, coupled with the fact that Mason Pocket occurs in a zone of reversed polarity, indicate that Mason Pocket is correlative to polarity Chron C26r, and not C25r as determined by Butler and others (1981).

Specimens from localities above Mason Pocket in the "Tiffany beds" suggest a significantly younger age. A specimen (AMNH 55499) identified as Dipsalidictis aequidens (Oxyaena of Butler and others, 1981, p. 309) by Gunnell and Gingerich (1991, p. 156), reportedly collected several kilometers northwest of Mason Pocket, suggests a Clarkforkian age. Dipsalidictis aequidens is known only from the Clarkforkian (Cf-2, Cf-3) in the Bighorn Basin and elsewhere (Gunnell and Gingerich, 1991). Similarly, specimens from the "Tiffany beds" tentatively identified as Phenacodus vortmani by Thewissen (1990, p. 15, p. 58-59) suggest a late Tiffanian (Ti-5, Ti-6) or Clarkforkian age. Phenacodus vortmani first appears near the base of the Probathyopsis zone (Ti-5a) in the Bighorn Basin (fig. 9) and is not known from localities older than Ti-5 regionally (Thewissen, 1990).

Butler and others (1981, fig. 7) sampled a $150 \mathrm{~m}$ thick section through the "Tiffany beds" with Mason Pocket near the base and reported that the entire section had reversed polarity. The presence of Phenacodus vortmani and Dipsalidictis in the "Tiffany beds" along with the Mason Pocket fauna suggests that this thin unit spans a large temporal range. If this section does include strata of Tiffanian through Clarkforkian age, however, one would expect to find two normal polarity zones (C26n and C25n, fig. 3). It may be that the section contains significant hiatuses or that paleomagnetic sampling was incomplete. Other possibilities are that the identification or provenance of specimens is incorrect (see Thewissen, 1990, p. 15) or that the age ranges of Dipsalidictis and Phenacodus vortmani differ considerably from southern Colorado to northern Wyoming. This last idea is unlikely, however, because there is no evidence that Mason Pocket contains taxa that have greatly disparate age ranges elsewhere. In other words, taxa that occur together at Mason Pocket also occur together in northern Wyoming. A better understanding of the age range of the "Tiffany beds" requires the collection of additional specimens, new paleomagnetic sampling, and the placement of localities into a stronger lithostratigraphic and chronostratigraphic framework.

\section{CONCLUSIONS}

The radioisotopic age of the Belt Ash corroborates previous correlation of the Bighorn Basin magnetostratigraphy to the GPTS by Butler and others $(1981,1987)$. The ash occurs slightly below the zone C26r-C26n reversal on Polecat Bench $(\sim 40 \mathrm{~m})$, and thus provides an important calibration point for this reversal and by association for the Selandian-Thanetian stage boundary (Luterbacher and others, 2004; Ogg and Smith, 2004). The ${ }^{40} \mathrm{Ar} /{ }^{39} \mathrm{Ar}$ age of the Belt Ash agrees closely with magnetostratigraphic age estimates using the GPTS of Ogg and Smith (2004). Thus, it corroborates their interpretation that polarity Chron C26n is significantly older than depicted in the GPTS of Cande and Kent (1995).

The identification of Chron C26n in Foster Gulch provides an important tie point to the Polecat Bench sequence and to the GPTS, and it greatly strengthens the chronostratigraphic framework of the northern Bighorn Basin. Our biostratigraphic revision, coupled with paleomagnetic data, indicate that Mason Pocket, the primary fauna upon which the Tiffanian land-mammal age was originally based, is correlative to Chron C26r, rather than C25r, as previously thought. Our revision of middle and late 
Paleocene biozones and a detailed description of their content provide a strong basis for regional biostratigraphic correlation. Age calibration of these biozones using the revised GPTS places the contained Bighorn Basin biotas into a high resolution geochronologic context allowing faunal and floral records to be compared to those from other basins and other continents, and to the paleoclimate record. It also provides a robust framework for testing the synchrony of taxonomic first and last appearances, and helps to constrain the timing of important immigration and evolutionary events.

\section{ACKNOWLEDGMENTS}

We are grateful to M. O. Woodburne and J. A. Lillegraven for their reviews of this manuscript, which improved it. We are also grateful to J. I. Bloch, D. C. Fisher, G. F. Gunnell, W. J. Sanders, and G. R. Smith for their help, guidance, and comments; to D. Boyer, J. Finarelli, C. Labandeira, P. Rose, and I. Zalmout for help with field work; to N. B. Beranek, P. H. Jun, W. J. Sanders, and M. R. Stocker for specimen preparation; to C. E. Badgley and K. D. Rose for helpful comments; to P. Higgins for providing data from her dissertation; to M. A. Tuner, D. Brinkman, L. Murray, and M. Fox for help with specimens in the Yale Peabody Museum; and to J. G. Ogg for providing timely pre-publication data from the Geologic Time Scale 2004. This research was partially supported by grants from the Petroleum Research Fund of the American Chemical Society (36318-AC8 to P. D. G. and 35229-G2 to P. W.), the National Science Foundation (EAR-0125502 to P. D. G., EAR-0001379 to W. C. C., and EAR-0114055 to B. S. S.), and the Geological Society of America and Department of Geological Sciences, University of Michigan (to R. S.).

\section{Appendix A}

Correlation across Polecat Bench and to Foster Gulch

The composite section used to compile stratigraphic ranges in figure 9 relies in part on correlation of sections across Polecat Bench and correlation of Foster Gulch faunas to Polecat Bench. The West Polecat Bench section (WPB) was correlated to the southeast section (SPB) using the top of polarity zone C26n and the base of C25n. Because the top of C25n is covered on WPB, localities above C25n were correlated using stratigraphic distance below the Paleocene-Eocene boundary (CIE) which occurs at the southwestern tip of Polecat Bench (fig. 1) (Rose, 1981; Gingerich, 2001). As noted above, paleomagnetic correlations across Polecat Bench demonstrate that accumulation rates were nearly equal across Polecat Bench from Ti- $4 \mathrm{~b}$ to Ti-6, and we assume that rates remained the same during the Clarkforkian.

Foster Gulch is approximately $40 \mathrm{~km}$ east-southeast of the southeastern margin of Polecat Bench (Bloch and others, 2004, fig. 1). Three important Tiffanian quarries, Cedar Point, Divide (FG-46), and Croc Tooth (FG-28 or "Witter") quarries occur in the area. Cedar Point and Divide quarries are considered here to be the representative faunas for the $P$. rex (Ti-3) and $P$. churchilli $(\mathrm{Ti}-4 \mathrm{a})$ biozones, respectively. The quarries have yielded 1988 and 483 identified jaws and teeth, respectively (Rose, 1981; Secord, ms, 2004), which are the largest single collections from Ti-3 and Ti-4a in the Bighorn Basin. Croc Tooth Quarry yielded a smaller sample (at least 70 identified specimens, 22 species; Secord, ms, 2004, pp. 504-506) but is important for its faunal content and stratigraphic position above Divide Quarry. The primary tie point between Polecat Bench and Foster Gulch is the C26r-C26n polarity reversal, discussed in the "Magnetostratigraphy" section.

The best supported biostratigraphic correlation from Foster Gulch to SPB below C26n is Croc Tooth Quarry, which correlates to SC-243 (Secord, ms, 2004, p. 25), but with the recognition of the C26r-C26n polarity reversal directly above these localities (fig. 2), further discussion is unwarranted. Fossil samples of Tiffanian age below SC-243 on Polecat Bench are relatively small, but provisional correlations are possible. We correlate Cedar Point Quarry to localities SC-263, SC-412, and SC-415 on Polecat Bench based on the mutual presence of Arctocyon cf. mumak, Neoplagiaulax hunteri, and Ptilodus sp. C. None of these taxa ranges into Ti-4a in the Bighorn Basin, nor does Titanoides cf. major, which occurs slightly higher at SC-262 (fig. 2). The lower boundary of SC-263, as originally defined, extends considerably lower than SC-412 and SC-415 (fig. 2). Strata below SC-412 are poorly fossiliferous, however, and it appears that specimens from SC-263 are 
from a narrow stratigraphic interval approximately equivalent to SC-412 and SC-415. The absence of $P$. anceps at these localities precludes assignment to Ti-2. Only two specimens of Plesiadapis are known from this level, but UM 109619 ( ${ }^{1}$; SC-412) has a mesostyle, a feature not known in P. anceps (see Gingerich, 1976, p. 26). Both specimens are within the size range of $P$. rex and $P$. churchilli, but would be large for $P$. anceps (see Gingerich, 1976, p. 111, for measurements of $P$. anceps and $P$. rex, and Secord, ms, 2004, p. 344, for $P$. churchilli). These teeth presumably are those of $P$. rex based on the associated fauna, but larger samples are needed for confident identification.

Divide Quarry is correlated to SC-261 on Polecat Bench based on the mutual presence of Lambertocyon and Titanoides gidleyi (fig. 2). Neither of these taxa is known from Ti-3. SC-261 is distinguished from Ti-4b faunas by the absence of Cyriacotherium argyreum, Phenacolemur, and Plesiadapis cf. fodinatus. Another indicator of Ti-4 equivalence for SC-261 is the abundance of Ptilodus kummae, which is known from five specimens that account for about one-third of the sample. Ptilodus kummae is a common species in Ti-4 faunas and accounts for 24 percent of the specimens at Divide Quarry (Secord, ms, 2004, pp. 502-503). It is a rare species at Cedar Point Quarry, however, if present at all (Secord, ms, 2004, pp. 63-65). A single tooth of Plesiadapis is known from SC-261 (UM 73388, $\mathrm{M}_{2}$ ). It is near the mean size for P. churchilli from Divide Quarry (Secord, ms, 2004, p. 344) but is also within the size range of $P$. rex from Cedar Point Quarry (Gingerich, 1976, p. 111). It presumably belongs to the former, but a larger sample is needed for confident identification.

Long Draw Quarry in the northern Bighorn Basin of Montana is the type locality for Plesiadapis churchilli, and it appears to be a correlative of Divide Quarry and Ti-4a. It has yielded a considerably smaller sample than Divide Quarry (at least 22 identified specimens, 11 species), however, and is an isolated locality well removed from the main sections (UTM: 12T, E 668500, N 4989200, NAD 1927). Faunal lists for Divide and Long Draw quarries were reported by Secord (ms, 2004, pp. 502-504). 
Appendix B

Complete ${ }^{40} \mathrm{Ar} /{ }^{39} \mathrm{Ar}$ geochronology results for the Belt Ash (table B1)

TABLE B1

All analyses are for twenty crystal aliquots. All ages calculated relative to 28.34 Ma for the Taylor Creek Rhyolite sanidine (Renne and others, 1998) using decay constants of Steiger and Jäger (1977). Uncertainties in Ar isotope ratios are reported at 10 analytical precision. Uncertainties in ages are reported at $2 \sigma$ analytical precision. Isotopic ratios are corrected for ${ }^{37} \mathrm{Ar}$ and ${ }^{39} \mathrm{Ar}$ decay, which have half lives of 35.2 days and 269 years, respectively. Corrections for undesirable nucleogenic reactions on ${ }^{40} \mathrm{~K}$ and ${ }^{40} \mathrm{Ca}$ are as follows: $\left[^{40} \mathrm{Ar}{ }^{39} \mathrm{Ar}\right]_{\mathrm{K}}=0.00165 ;\left[^{36} \mathrm{Ar}{ }^{39} \mathrm{Ar}\right]_{\mathrm{Ca}}=0.000269 ;\left[^{39} \mathrm{Ar} /{ }^{37} \mathrm{Ar}\right]_{\mathrm{Ca}}=0.000709$

\begin{tabular}{|c|c|c|c|c|c|c|c|}
\hline Sample & ${ }^{40} \mathrm{Ar} /{ }^{39} \mathrm{Ar}$ & $\begin{array}{l}{ }^{37} \mathrm{Ar} /{ }^{39} \mathrm{Ar} \\
\left(\mathrm{x} 10^{-2}\right)\end{array}$ & $\begin{array}{c}{ }^{36} \mathrm{Ar} /{ }^{39} \mathrm{Ar} \\
\left(\mathrm{x} 10^{-3}\right)\end{array}$ & $\begin{array}{c}{ }^{40} \mathrm{Ar}^{\star} \\
\left(\times 10^{-14} \mathrm{~mol}\right)\end{array}$ & $\%{ }^{40} \mathrm{Ar}{ }^{*}$ & $\mathrm{~K} / \mathrm{Ca}$ & $\begin{array}{c}\text { Apparent Age } \\
\pm 2 \sigma \mathrm{Ma} \\
\end{array}$ \\
\hline \multicolumn{8}{|c|}{ sanidine $\mathrm{J}=0.013363 \pm 0.1 \% \mu=1.0024 \pm 0.1 \%$} \\
\hline UW21A7a & $2.532 \pm 0.006$ & $0.783 \pm 0.095$ & $0.243 \pm 0.232$ & 0.37 & 97.15 & 54.9 & $58.35 \pm 3.21$ \\
\hline UW21A7b & $2.671 \pm 0.005$ & $0.797 \pm 0.040$ & $0.668 \pm 0.087$ & 0.88 & 92.61 & 53.9 & $58.67 \pm 1.23$ \\
\hline UW21A7c & $2.758 \pm 0.007$ & $0.840 \pm 0.044$ & $0.944 \pm 0.061$ & 1.03 & 89.88 & 51.2 & $58.78 \pm$ \\
\hline UW $21 A 7 \mathrm{~d}$ & $3.956 \pm 0.006$ & $1.830 \pm 0.035$ & $4.981 \pm 0.078$ & 1.69 & 62.81 & 23.5 & $58.92 \pm 1.11$ \\
\hline UW21A7e & $4.198 \pm 0.010$ & $1.217 \pm 0.027$ & $5.894 \pm 0.076$ & 2.06 & 58.51 & 35.3 & $58.26 \pm 1.12$ \\
\hline \multicolumn{8}{|c|}{ sanidine $\mathrm{J}=0.014538 \pm 0.1 \% \mu=1.0035 \pm 0.1 \%$} \\
\hline UW32Cl0a & $2.310 \pm 0.006$ & $0.836 \pm 0.034$ & $0.170 \pm 0.152$ & 0.50 & 97.78 & 51.4 & $58.29 \pm 2.30$ \\
\hline UW $32 \mathrm{Cl} 10 \mathrm{~b}$ & $2.309 \pm 0.006$ & $0.780 \pm 0.029$ & $0.068 \pm 0.096$ & 0.74 & 99.09 & 55.1 & .48 \\
\hline $\mathrm{UW} 32 \mathrm{C} 10 \mathrm{c}$ & $2.327 \pm 0.004$ & $0.726 \pm 0.016$ & $0.099 \pm 0.067$ & 1.34 & 98.70 & 59.2 & $59.24 \pm 1.02$ \\
\hline UW32C10d & $2.320 \pm 0.003$ & $0.734 \pm 0.017$ & $0.069 \pm 0.048$ & 1.48 & 99.08 & 58.6 & $59.31 \pm 0.74$ \\
\hline UW32C10e & $2.352 \pm 0.015$ & $0.761 \pm 0.064$ & $0.081 \pm 0.256$ & 0.26 & 98.94 & 56.5 & $60.03 \pm 3.91$ \\
\hline UW $32 \mathrm{C} 10 \mathrm{f}$ & $2.351 \pm 0.008$ & $0.735 \pm 0.024$ & $0.270 \pm 0.100$ & 0.59 & 96.56 & 58.5 & $58.59 \pm 1.54$ \\
\hline UW32C10g & $2.319 \pm 0.012$ & $0.745 \pm 0.058$ & $0.006 \pm 0.174$ & 0.36 & 99.87 & 57.7 & $59.74 \pm 2.68$ \\
\hline UW32C10h & $2.364 \pm 0.006$ & $0.756 \pm 0.035$ & $0.365 \pm 0.109$ & 0.56 & 95.40 & 56.9 & $58.20 \pm 1.66$ \\
\hline UW32C10i & $2.343 \pm 0.009$ & $0.748 \pm 0.036$ & $0.204 \pm 0.132$ & 0.50 & 97.39 & 57.5 & $58.87 \pm 2.03$ \\
\hline UW32C10j & $2.331 \pm 0.009$ & $0.688 \pm 0.044$ & $0.009 \pm 0.165$ & 0.35 & 99.84 & 62.5 & $60.04 \pm 2.52$ \\
\hline UW32C10k & $2.326 \pm 0.006$ & $0.749 \pm 0.022$ & $0.121 \pm 0.080$ & 0.86 & 98.42 & 57.4 & $59.06 \pm 1.24$ \\
\hline UW32C10I & $2.330 \pm 0.005$ & $0.767 \pm 0.015$ & $0.091 \pm 0.070$ & 0.97 & 98.80 & 56.0 & $59.40 \pm 1.08$ \\
\hline UW $32 \mathrm{C} 10 \mathrm{~m}$ & $2.314 \pm 0.004$ & $0.722 \pm 0.021$ & $0.098 \pm 0.082$ & 1.11 & 98.71 & 59.6 & $58.92 \pm 1.25$ \\
\hline UW32C10n & $2.382 \pm 0.012$ & $0.678 \pm 0.043$ & $0.206 \pm 0.240$ & 0.37 & 97.40 & 63.4 & $59.85 \pm 3.65$ \\
\hline UW $32 \mathrm{C} 10^{\circ}$ & $2.348 \pm 0.007$ & $0.751 \pm 0.021$ & $0.114 \pm 0.216$ & 0.48 & 98.53 & 57.2 & $59.67 \pm 3.26$ \\
\hline UW $32 \mathrm{C} 10 \mathrm{p}$ & $2.340 \pm 0.007$ & $0.735 \pm 0.029$ & $0.118 \pm 0.126$ & 0.56 & 98.47 & 58.5 & $59.44 \pm 1.93$ \\
\hline UW32C10q & $2.321 \pm 0.005$ & $0.693 \pm 0.032$ & $0.049 \pm 0.139$ & 0.61 & 99.33 & 62.0 & $59.47 \pm 2.10$ \\
\hline UW $32 \mathrm{C} 10 \mathrm{r}$ & $2.325 \pm 0.005$ & $0.741 \pm 0.031$ & $0.123 \pm 0.096$ & 0.50 & 98.39 & 58.0 & $59.01 \pm 1.46$ \\
\hline
\end{tabular}

Inverse isochron age $\pm 2 \sigma=59.11 \pm 0.34^{*}$; Mean squared weighted deviation $=0.36$; Intercalibration and analytical uncertainties $= \pm 0.34 ; *$ Analytical uncertainties; ${ }^{40} \mathrm{Ar} /{ }^{39} \mathrm{Ar}$ intercept $\pm 2 \sigma=290.9 \pm 6.8$; Total fusion age $\pm 2 \sigma=59.09 \pm 0.33$; Weighted mean age $\pm 2 \sigma=59.00 \pm 0.30 *$; Fully propagated uncertainties $= \pm 1.05$. 


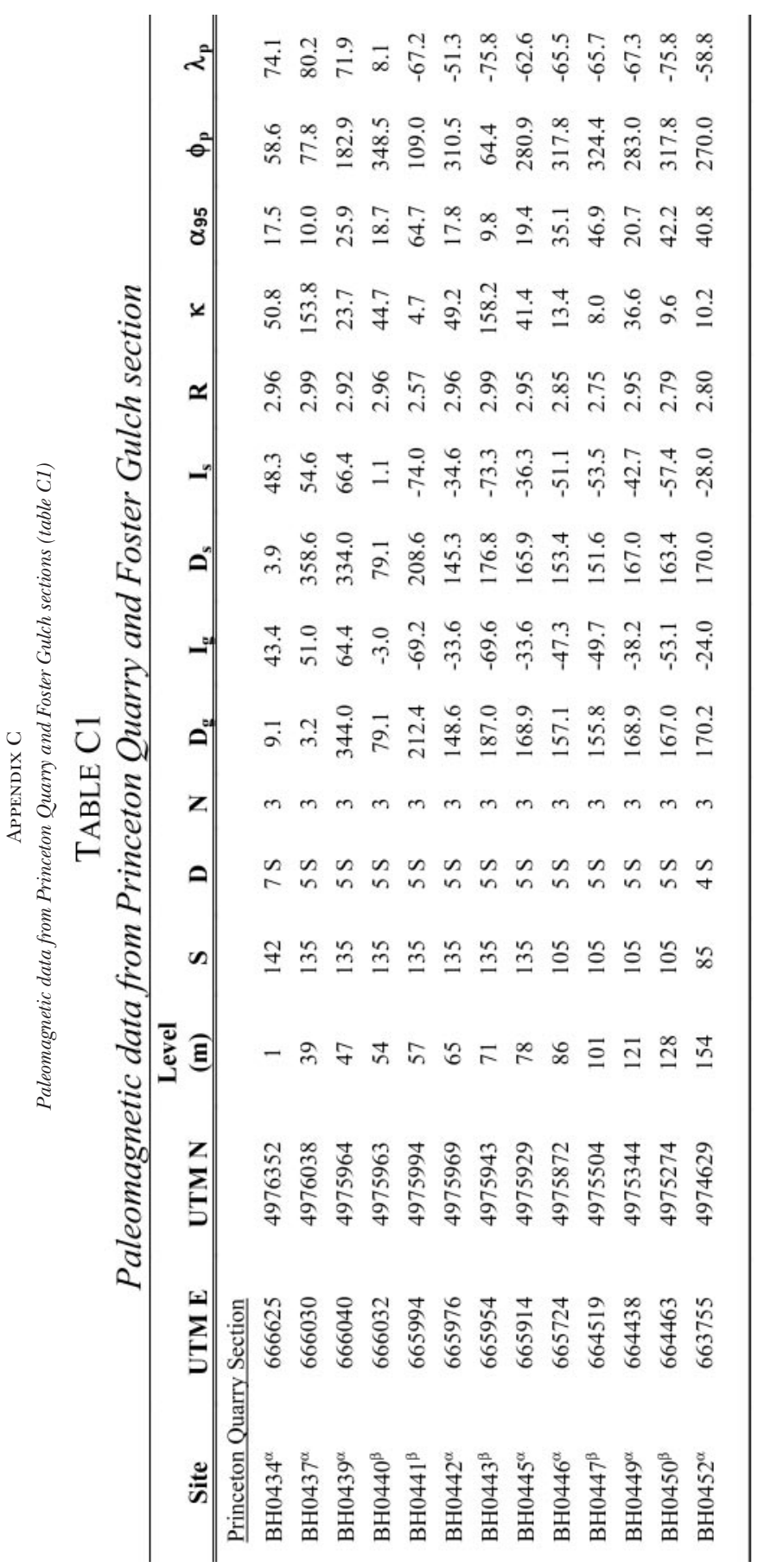




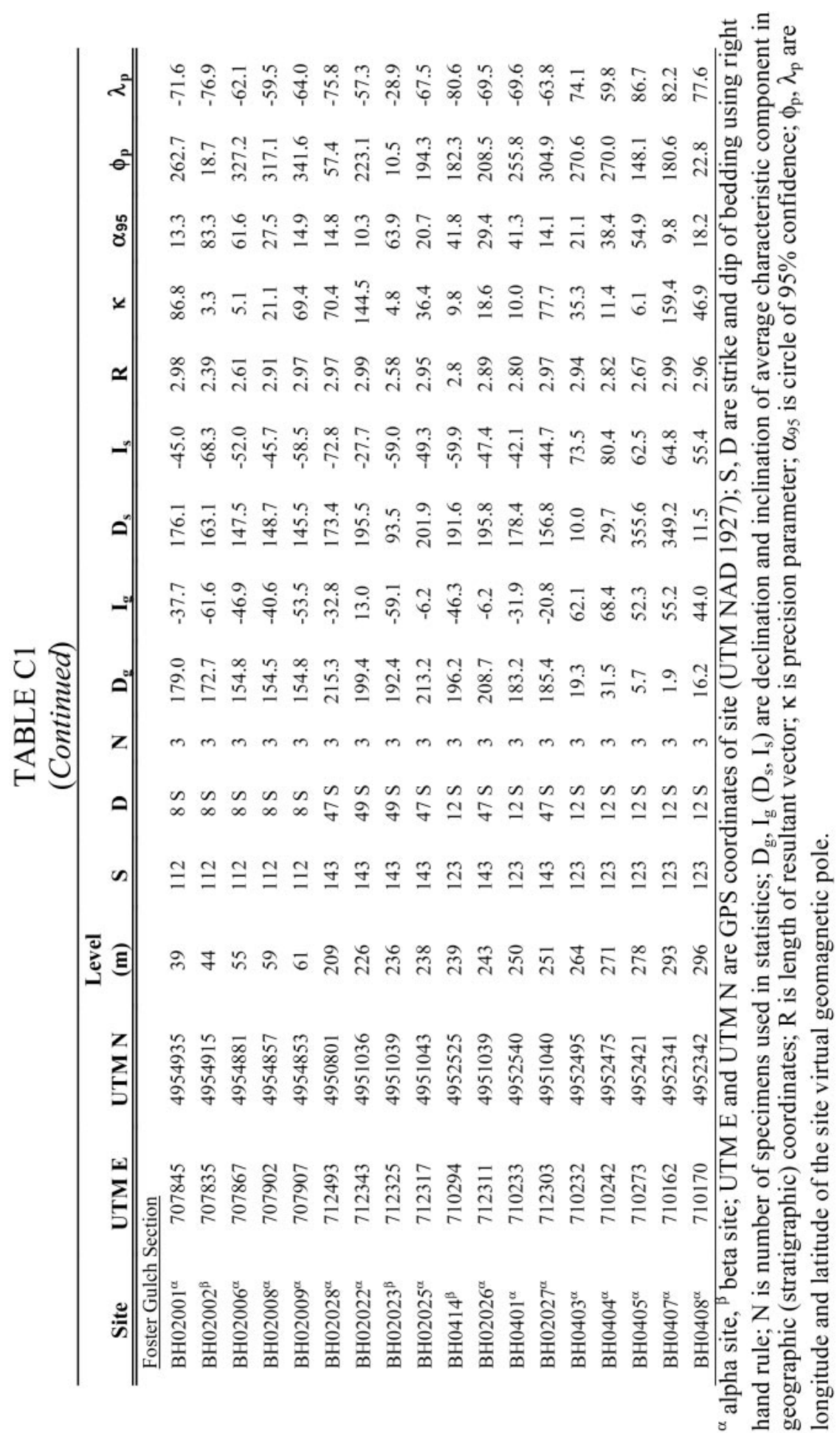




\section{Appendix D \\ Definitions and Descriptions of New and Revised Biozones}

Descriptions or references to descriptions for species listed below, along with locality data, can be found in Secord (ms, 2004) for Tiffanian species, and Rose (1981), Archibald and others (1987), and Lofgren and others (2004) for Clarkforkian species. Stratigraphic levels for boundaries are provided in table 1.

Phenacolemur interval zone (Ti-4b, new zone).-The Phenacolemur zone is the interval between the first occurrences of Phenacolemur and Probathyopsis. Ti-4b is best represented by Croc Tooth Quarry in Foster Gulch, and by SC-243 and Fossil Hollow (SC-198) on the southeast and western sides of Polecat Bench (fig. 2). It should be noted that Fossil Hollow was previously placed at a considerably higher level above Princeton Quarry and considered to be in the P. simonsi zone (Ti-5a, Gingerich, 2001, fig. 2, p. 40). New measured sections clearly indicate that Fossil Hollow is well below Princeton Quarry, although the level depicted in figure 2 is based on long bed traces and could be off by several tens of meters.

The Phenacolemur zone is given a Ti-4 abbreviation because it contains $P$. churchilli and occupies what was previously the P. churchilli zone (fig. 3). The most common species of Phenacolemur in the Phenacolemur zone is a new unnamed species known from several localities, including the representative ones given above (Secord, ms, 2004, pp. 259-263). The new species co-occurs with P. pagei at Fossil Hollow based on specimens in the YPM collections. Sample sizes are much larger for Ti-5a than for Ti-4b, and many Ti-5a taxa probably will be found lower with better sampling in Ti-4b.

First occurrences: Arctocyon cf. nexus, Carpolestes (C. cf. dubius), Cyriacotherium argyreum, Didymictis dellensis, Dipsalodon (D. churchillorum), Ectocion mediotuber*, Ectoganus (E. lobdelli), Lambertocyon eximius*, Phenacolemur pagei, Prochetodon cavus*, Thryptacodon pseudarctos, and Viverravus schaff. Carpolestes and Dipsalodon are distinctive genera and their first occurrences may be especially useful. Ectoganus is a relatively rare taxon known only from floodplain deposits and may have been restricted to specialized environments.

Last occurrences: Aaptoryctes cf. ivyi, Arctocyon mumak, Bessoecetor new species, Chiromyoides caesor, Ectocion cedrus*, Haplolambda cf. quinni, Ignacius frugivorus, Lambertocyon (L. eximius), Leptolambda churchilli, Neoplagiaulax mckennai, Ptilodus (P. kummae), and Titanoides gidleyi. Ptilodus is one of the most common elements in many Ti-4 and older Tiffanian and Torrejonian zones, and its last occurrence in Ti-4b is an important biostratigraphic datum. Neoplagiaulax mckennai is an easily recognized Ti-4(a and b) index species.

Known only in the Phenacolemur zone: Phenacolemur new species and Plesiadapis cf. fodinatus*.

Additional species present: Adunator minutus, Phenacodus grangeri, Phenacodus magnus, and Plesiadapis churchilli.

Probathyopsis interval zone (Ti-5a, revised).-The Probathyopsis zone is the interval between the first occurrences of Probathyopsis and Plesiadapis simonsi. The type area is on the west side of Polecat Bench. Princeton and Schaff quarries are representative faunas.

Probathyopsis was recently synonymized with Prodinoceras by Lucas and Schoch (1998) following Schoch and Lucas (1985). We follow Thewissen and Gingerich (1987), however, and recognize Probathyopsis as a valid genus for reasons cited therein (pp. 216-217).

$\mathrm{An}_{3}$ of Probathyopsis (YPM-PU 18350) in the YPM collections is labeled as coming from Fossil Hollow which, if true, would lower the base of the Probathyopsis zone $\sim 95 \mathrm{~m}$ on WPB and make the composite Phenacolemur zone $\sim 60 \mathrm{~m}$ thinner. Jepsen's 1937 unpublished field notes indicate that the tooth (in notes as ? Titanoides) is from the "same level as Fossil Hollow." Fossil Hollow is geographically removed from other localities in the area, however, and there are few fossiliferous exposures nearby. Additionally, the labels on some YPM-PU specimens collected about 100 meters higher in exposures below Schaff Quarry are marked as being from the "Fossil Hollow level." This is near the level of the first confident occurrences of Probathyopsis at WPB. Thus, the provenance of YPM-PU 18350 is in doubt. Probathyopsis is not known from any Ti-4 faunas outside the Bighorn Basin (Lofgren and others, 2004, table 3.2, Prodinoceras) and, while its range may be extended downward with additional collecting, it is improbable that it will be found as low as the P. churchilli zone.

Phenacodus vortmani is potentially useful for recognition of the Ti-4b\Ti-5a boundary. It first occurs at approximately the same level as Probathyopsis (fig. 9) and does not appear to occur in earlier faunas outside the Bighorn Basin (Thewissen, 1990).

First occurrences: Arctodontomys sp., Arctostylopidae (Arctostylops steini), Carpolestes dubius*, Dinocerata (Probathyopsis harrisorum), Dissacus argenteus, Ectypodus powelli, Leptacodon packi, Litolestes ignotus, Microcosmodon conus, Neoliotomus conventus, Parectypodus laytoni, Phenacodaptes sabulosus, Phenacodus vortmani, Plesiadapis fodinatus*, Princetonia $\mathrm{cf}$. yalensis, Prodiacodon cf. tauricinerei, Unuchinia $\mathrm{cf}$. dysmathes, and Viverravus laytoni.

Last occurrences: Dipsalodon churchillorum, Ectoganus cf. lobdelli*, Peradectes elegans, Phenacodus magnus, Plesiadapis churchilli*, and Thryptacodon australis.

Known only in the Probathyopsis zone: Micromomys new species A, Micromomys silvercouleei, Mimetodon churchilli, Neoplagiaulax hazeni, Paleotomus cf. radagasti, Pentacosmodon pronus, Prodiacodon new species, Propalaeanodon schaffi, Wyonycteris new species A, and Wyonycteris new species B.

Additional species present: Adunator minutus, Aletodon sp., Arctocyon cf. nexus, Chiromyoides cf. caesor, Cyriacotherium argyreum, Didymictis dellensis, Ectocion mediotuber, Labidolemur soricoides, Palaeoryctes jepseni, Phenacolemur pagei, Phenacodus grangeri, Prochetodon cavus, Thryptacodon pseudarctos, and Viverravus schaff.

Copecion interval zone $(C f-3)$. - The Copecion zone is the interval between the first occurrences of Copecion and Meniscotherium (see Gingerich, 2001, for discussion of Meniscotherium zone). It replaces the Phenacodus- 
Ectocion acme zone of Rose (1980, 1981) and Gingerich (2001). The first occurrence of Copecion is slightly below $(\sim 15 \mathrm{~m})$ the last appearance of $P$. cookei. For this reason previous reports included Copecion in Cf-2 (Thewissen, 1990, p. 66; Lofgren and others, 2004). Several productive localities that were previously included in the P. cookei range zone (SC-19, SC-62, SC-117, Rose, 1981) are now included in the Copecion zone.

First occurrences: Copecion brachypternus, Dipsalidictis platypus, Dipsalidictis transiens, Hyopsodus sp., and Esthonyx grangeri*.

Last occurrences: Aletodon (A. gunnelli), Apheliscus nitidus*, Arctostylopidae (Arctostylops steini), Carpolestidae (Carpolestes simpsoni), Dipsalidictis aequidens, Dipsalidictis krausei, Dipsalodon (D. matthewi), Ectocion major, Ectypodus powelli, Esthonyx ancylion*, Haplomylus simpsoni, Ignacius cf. graybullianus*, Microcosmodon (M. rosei), Palaeoryctes* (P. punctatus), Plagiomene accola, Plesiadapidae (Chiromyoides major, Plesiadapis cookei, P. dubius), Probathyopsis (P. praecursor), Viverravus laytoni, and Worlandia (W. inusitata).

Known only in Copecion zone: Ceutholestes dolosus, Cyriacotherium psamminum, Limaconyssus habrus, Titanoides nanus, and Wyonycteris chalix.

Additional species present: Acritoparamys atavus, Acritoparamys atwateri, Adunator cf. minutus, Arctodontomys cf. wilsoni, Chriacus sp., Coryphodon proterus, Didymictis proteus, Dissacus praenuntius, Ectocion osbornianus, Ectoganus lobdelli, Labidolemur kayi, Leptacodon rosei, Microparamys cheradius, Neoliotomus sp., Niptomomys doreenae, Palaeanodon parvulus, Palaeonictis peloria, Palaeosinopa sp., Paramys taurus, Peradectes sp., Phenacodus intermedius, Phenacodus vortmani, Phenacolemur praecox, Plagioctenodon sp., Princetonia sp., Prodiacodon cf. tauricinerei, Thryptacodon cf. antiquus, Tinimomys graybulliensis, Uintacyon rudis, Viverravus acutus, and Viverravus politus.

*Part of a lineage with an evolutionary species known below (first occurrences) or above (last occurrences).

\section{REFERENCES}

Agterberg, F. P., 1988, Quality of time scales-a statistical appraisal, in Merriam, D. F., editor, Current trends in geomathematics: New York, Plenum Press, p. 57-103.

1994, Estimation of the Mesozoic geologic time scale: Mathematical Geology, v. 26, p. 857-876.

2004, Geomathematics, in Gradstein, F. M., Ogg, J. G., and Smith, A. G., editors, A Geologic Time Scale 2004: Cambridge, Cambridge University Press, p. 106-125.

Alroy, J., 1994, Appearance event ordination: a new biochronologic method: Paleobiology, v. 20, p. $191-207$. 2000, New methods for quantifying macroevolutionary patterns and processes: Paleobiology, v. 26, p. 707-733.

Archibald, J. D., Gingerich, P. D., Lindsay, E. H., Clemens, W. A., Krause, D. W., and Rose, K. D., 1987, First North American land mammal ages of the Cenozoic Era, in Woodburne, M. O., editor, Cenozoic mammals of North America, geochronology and biostratigraphy: Berkeley, University of California Press, p. 24-76.

Beard, K. C., and Dawson, M. R., 1999, Intercontinental dispersal of Holarctic land mammals near the Paleocene/Eocene boundary: paleogeographic, paleoclimatic and biostratigraphic implications: Bulletin de la Société Géologique de France, v. 170, p. 697-706.

Belt, E. S., Hartman, J. H., Diemer, J. A., Kroeger, T. J., Tibert, N. E., and Curran, H. A., 2004, Unconformities and age relationships, Tongue River and older members of the Fort Union Formation (Paleocene), western Williston Basin, U.S.A.: Rocky Mountain Geology, v. 39, p. 113-140.

Berggren, W. A., and Van Couvering, J. A., 1978, Biochronology, in Cohee, G. V., Glaessner, M. F., and Hedberg, H. D., editors, Contributions to the geologic time scale, Volume 6: Tulsa, The American Association of Petroleum Geologists, p. 39-55.

Berggren, W. A., Kent, K. V., Swisher, C. C., III, and Aubry, M. P., 1995, A revised Cenozoic geochronology and chronostratigraphy, in Berggren, W. A., Kent, D. V., Aubry, M. P., and Hardenbol, J., editors, Geochronology, time scales and global stratigraphic correlation: Society of Economic Paleontologists and Mineralogists, Special Publication 54, p. 130-212.

Bloch, J. I., ms, 2001, Mammalian paleontology of freshwater limestones from the Paleocene-Eocene of the Clarks Fork Basin, Wyoming: Ann Arbor, Michigan, University of Michigan, Ph.D. thesis, 358 p.

Bloch, J. I., Secord, R., and Gingerich, P. D., 2004, Systematics and phylogeny of late Paleocene and early Eocene Palaeoryctinae (Mammalia, Insectivora) from the Clarks Fork and Bighorn basins, Wyoming: Contributions from the Museum of Paleontology, University of Michigan, v. 31, p. 119-154.

Bown, T. M., and Kraus, M. J., 1981, Lower Eocene alluvial paleosols (Willwood Formation, northwest Wyoming, U.S.A.) and their significance for paleoecology, paleoclimatology, and basin analysis: Palaeogeography, Palaeoclimatology, Palaeoecology, v. 34, p. 1-30.

Bown, T. M., and Rose, K. D., 1976, New early Tertiary primates and a reappraisal of some Plesiadapiformes: Folia Primatologica, v. 26, p. 109-138.

Butler, R. F., Gingerich, P. D., and Lindsay, E. H., 1981, Magnetic polarity stratigraphy and biostratigraphy of Paleocene and lower Eocene continental deposits, Clarks Fork Basin, Wyoming: Journal of Geology, v. 89 , p. $299-316$. 
Butler, R. F., Krause, D. W., and Gingerich, P. D., 1987, Magnetic polarity stratigraphy and biostratigraphy of middle-late Paleocene continental deposits of south-central Montana: Journal of Geology, v. 95, p. $647-657$.

Cande, S. C., and Kent, D. V., 1992, A new geomagnetic polarity timescale for the Late Cretaceous and Cenozoic: Journal of Geophysical Research, v. 97, p. 13917-13951.

1995, Revised calibration of the geomagnetic polarity timescale for the Late Cretaceous and Cenozoic: Journal of Geophysical Research, v. 100, p. 6093-6095.

Clyde, W. C., ms, 1997, Stratigraphy and mammalian paleontology of the McCullough Peaks, northern Bighorn Basin, Wyoming: implications for biochronology, basin development, and community reorganization across the Paleocene-Eocene boundary: Ann Arbor, Michigan, University of Michigan, Ph.D. thesis, $270 \mathrm{p}$.

- 2001, Mammalian biostratigraphy of the McCullough Peaks area in the northern Bighorn Basin, in Gingerich, P. D., editor, Paleocene-Eocene stratigraphy and biotic change in the Bighorn and Clarks Fork basins, Wyoming: University of Michigan Papers on Paleontology No. 33, p. 109-126.

Davies-Vollum, K. S., 2001, Not just red beds: the occurrence and formation of drab sections in the Willwood Formation of the Bighorn Basin, in Gingerich, P. D., editor, Paleocene-Eocene stratigraphy and biotic change in the Bighorn and Clarks Fork basins, Wyoming: University of Michigan Papers on Paleontology No. 33, p. 29-35.

DeCelles, P. G., Gray, M. B., Ridgeway, K. D., Cole, R. B., Srivastava, P., Pequera, N., and Pivnik, D. A., 1991, Kinematic history of a foreland uplift from Paleocene synorogenic conglomerate, Beartooth Range, Wyoming and Montana: Geological Society of America Bulletin, v. 103, p. 1458-1475.

Diehl, J. F., Beck, M. E., Jr., Beske-Diehl, S., Jacobson, D., and Hearn, B. C., Jr., 1983, Paleomagnetism of the Late Cretaceous-Early Tertiary north-central Montana Alkalic Province: Journal of Geophysical Research, v. 88, p. 10,593-10,609.

Duffield, W. A., and Dalrymple, G. B., 1990, The Taylor Creek Rhyolite of New Mexico: rapidly emplaced field of lava domes and flows: Bulletin of Volcanology, v. 52, p. 475-487.

Fricke, H. C., Clyde, W. C., O’Neil, J. R., and Gingerich, P. D., 1998, Evidence for rapid climate change in North America during the latest Paleocene thermal maximum: oxygen isotope compositions of biogenic phosphate from the Bighorn Basin (Wyoming): Earth and Planetary Science Letters, v. 160, p. 193-208.

Gingerich, P. D., 1973, First record of Paleocene primate Chiromyoides from North America: Nature, v. 244, p. 517-518.

1975, New North American Plesiadapidae (Mammalia, Primates) and a biostratigraphic zonation of the middle and upper Paleocene: Contributions from the Museum of Paleontology, University of Michigan, v. 24, p. 135-148.

1976, Cranial anatomy and evolution of early Tertiary Plesiadapidae: University of Michigan Papers on Paleontology No. 15, 140 p.

1983a, Paleocene-Eocene faunal zones and a preliminary analysis of Laramide structural deformation in the Clark's Fork Basin, Wyoming: Guidebook Wyoming Geological Association, v. 34, p. 185-195.

— 1983b, New Adapisoricidae, Pentacodontidae, and Hyopsodontidae (Mammalia, Insectivora and Condylarthra) from the late Paleocene of Wyoming and Colorado: Contributions from the Museum of Paleontology, University of Michigan, v. 26, p. 227-255.

1985, South American mammals in the Paleocene of North America, in Stehli, F. G., and Webb, S. D., editors, The great American biotic interchange: New York, Plenum Press, p. 123-137.

1989, New earliest Wasatchian mammalian fauna from the Eocene of northwestern Wyoming: composition and diversity in a rarely sampled high-floodplain assemblage: University of Michigan Papers on Paleontology No. 28, 97 p.

2001, Biostratigraphy of the continental Paleocene-Eocene boundary interval on Polecat Bench in the northern Bighorn Basin, in Gingerich, P. D., editor, Paleocene-Eocene stratigraphy and biotic change in the Bighorn and Clarks Fork basins, Wyoming: University of Michigan Papers on Paleontology No. 33 , p. 37-72.

2003, Mammalian responses to climate change at the Paleocene-Eocene boundary: Polecat Bench record in northern Bighorn Basin, Wyoming, in Wing, S. L., Gingerich, P. D., Schmitz, B., and Thomas, E., editors, Causes and consequences of globally warm climates in the early Paleogene: Geological Society of America Special Paper 369, p. 463-478.

Gingerich, P. D., and Clyde, W. C., 2001, Overview of mammalian biostratigraphy in the Paleocene-Eocene Fort Union and Willwood formations of the northern Bighorn and Clarks Fork basins, in Gingerich, P. D., editor, Paleocene-Eocene stratigraphy and biotic change in the Bighorn and Clarks Fork basins, Wyoming: University of Michigan Papers on Paleontology No. 33, p. 1-14.

Gradstein, F. M., Agterberg, F. P., Ogg, J. G., Hardenbol, J., van Veen, P., Thierry, J., and Huang, Z., 1995, A Triassic, Jurassic and Cretaceous time scale, in Berggren, W. A., Kent, D. V., Aubry, M. P., and Hardenbol, J., editors, Geochronology, time scales, and global stratigraphic correlation: Society of Economic Paleontologists and Mineralogists, Special Publication 54, p. 95-126.

Graham, A., 1999, Late Cretaceous and Cenozoic history of North American vegetation, north of Mexico: New York, Oxford University Press, 370 p.

Granger, W., 1917, Notes on Paleocene and lower Eocene mammal horizons of northern New Mexico and southern Colorado: Bulletin of the American Museum of Natural History, v. 37, p. 821-830.

Gunnell, G. F., and Bartels, W. S., 2001, Basin-margin vertebrate faunas on the western flank of the Bighorn and Clarks Fork basins, in Gingerich, P. D., editor, Paleocene-Eocene stratigraphy and biotic change in the Bighorn and Clarks Fork basins, Wyoming: University of Michigan Papers on Paleontology No. 33, p. 145-155. 
Gunnell, G. F., and Gingerich, P. D., 1991, Systematics and evolution of late Paleocene and early Eocene Oxyaenidae (Mammalia, Creodonta) in the Clarks Fork Basin, Wyoming: University of Michigan, Contributions from the Museum of Paleontology, v. 28, p. 141-180.

Harland, B. W., Cox, A. V., Llewellyn, P. G., Pickton, C. A. G., Smith, A. G., and Walters, R., 1982, A geologic time scale: Cambridge, Cambridge University Press, 131 p.

Harland, B. W., Armstrong, R. L., Cox, A. V., Craig, L. E., Smith, A. G., and Smith, D. G., 1990, A geologic time scale 1989: Cambridge, Cambridge University Press, 263 p.

Hartman, J. H., and Krause, D. W., 1993, Cretaceous and Paleocene stratigraphy and paleontology of the Shawmut Anticline and the Crazy Mountains Basin, Montana: road log and overview of recent investigations, in Hunter, L. D. V., editor, Field Conference Guidebook: Montana Geological Society, p. $71-84$.

Hartman, J. H., and Roth, B., 1998, Late Paleocene and early Eocene nonmarine molluscan faunal change in the Bighorn Basin, northwestern Wyoming and south-central Montana, in Aubry, M. P., Lucas, S. G. and Berggren, W. A., editors, Late Paleocene-early Eocene climatic and biotic events in the marine and terrestrial records: New York, Columbia University Press, p. 323-379.

Herbert, T. D., D'Hondt, D. L., Premoli, S. I., Erba, E., and Fischer, A. G., 1995, Orbital chronology of Cretaceous-Early Paleocene marine sediments, in Berggren, W. A., Kent, D. V., Aubry, M. P., and Hardenbol, J., editors, Geochronology, time scales and global stratigraphic correlation: Society of Economic Paleontologists and Mineralogists, Special Publication 54, p. 81-94.

Hickey, L. J., 1980, Paleocene stratigraphy and flora of the Clark's Fork Basin, in Gingerich, P. D., editor, Early Cenozoic paleontology and stratigraphy of the Bighorn Basin, Wyoming: University of Michigan Papers on Paleontology No. 24, p. 33-50.

— 1986, Road log_Red Lodge, Montana to Clark, Wyoming via Elk Basin and Powell, Wyoming: field trip through the facies of the Fort Union Formation, Geology of the Beartooth Uplift and adjacent basins: Montana Geological Society and Yellowstone Bighorn Research Association, p. 279-290.

Hickey, L. J., and Yuretich, R. F., 1997, The Belfry Member of the Fort Union Formation; an allocyclic lacustrine deposit of late middle Paleocene age in the Bighorn Basin, Montana and Wyoming, in Campen, E. B., editor, Bighorn Basin: 50 years on the frontier, evolution of the geology of the Bighorn Basin, 1997 field trip and symposium: Yellowstone Bighorn Research Association, p. 38-42.

Hicks, J. F., Johnson, K. R., Obradovich, J. D., Tauxe, L., and Clark, D., 2002, Magnetostratigraphy and geochronology of the Hell Creek and basal Fort Union formations of southwestern North Dakota and a recalibration of the age of the Cretaceous-Tertiary boundary, in Hartman, J. H., Johnson, K. R., and Nichols, D. J., editors, The Hell Creek Formation and the Cretaceous-Tertiary boundary in the northern Great Plains: an integrated continental record of the end of the Cretaceous: Geological Society of America Special Paper 361, p. 35-55.

Higgins, P., ms, 2000, Re-evaluation of the boundary between the Torrejonian and Tiffanian North American land mammal "ages," with description of a new fauna from the Hanna Basin, south-central Wyoming: Laramie, Wyoming, University of Wyoming, Ph.D. thesis, 222 p.

2003, A Wyoming succession of Paleocene mammal-bearing localities bracketing the boundary between the Torrejonian and Tiffanian North American land mammal "ages": Rocky Mountain Geology, v. 38, p. 247-280.

ISSC, 1994, International stratigraphic guide: a guide to stratigraphic classification, terminology, and procedure: Trondheim, Boulder, The International Union of Geological Sciences and the Geological Society of America, 214 p.

Jepsen, G. L., 1930, Stratigraphy and paleontology of the Paleocene of northeastern Park County, Wyoming: Proceedings of the American Philosophical Society, v. 69, p. 463-528.

1940, Paleocene faunas of Polecat Bench Formation, Park County, Wyoming, Part 1: Proceedings of the American Philosophical Society, v. 83, p. 217-341.

Koch, P. L., Zachos, J. C., and Gingerich, P. D., 1992, Correlation between isotope records in marine and continental carbon reservoirs near the Paleocene Eocene boundary: Nature, v. 358, p. 319-322.

Koch, P. L., Zachos, J. C., and Dettman, D. L., 1995, Stable isotope stratigraphy and paleoclimatology of the Paleogene Bighorn Basin (Wyoming, USA): Palaeogeography, Palaeoclimatology, Palaeoecology, v. 115, p. $61-89$

Kraus, M. J., 1997, Lower Eocene alluvial paleosols: pedogenic development, stratigraphic relationships, and paleosol/landscape associations: Palaeogeography, Palaeoclimatology, Palaeoecology, v. 129, p. 387406.

Krause, D. W., ms, 1982, Evolutionary history and paleobiology of early Cenozoic Multituberculata (Mammalia), with emphasis on the family Ptilodontidae: Ann Arbor, Michigan, Ph.D. thesis, 575 p.

Lofgren, D. L., Lillegraven, J. A., Clemens, W. A., Gingerich, P. D., and Williamson, T. E., 2004, Paleocene biochronology of North America: the Puercan through Clarkforkian land mammal ages, in Woodburne, M. O., editor, Late Cretaceous and Cenozoic mammals of North America: biostratigraphy and geochronology: New York, Columbia University Press, p. 43-105.

Lucas, S. G., and Schoch, R. M., 1998, Dinocerata, in Janis, C. M., Scott, K. M., and Jacobs, L. L., editors, Evolution of Tertiary Mammals of North America; Volume 1: Terrestrial carnivores, ungulates, and ungulatelike mammals: Cambridge, Cambridge University Press, p. 284-292.

Luterbacher, H. P., Ali, J. R., Brinkhuis, H., Gradstein, F. M., Hooker, J. J., Monechi, S., Ogg, J. G., Powell, J., Röhl, U., Sanfilippo, A., and Schmitz, B., 2004, The Paleogene Period, in Gradstein, F. M., Ogg, J. G., and Smith, A. G., editors, A Geologic Time Scale: Cambridge, Cambridge University Press, p. 384-408.

Magioncalda, R., Dupuis, C., Smith, T., Steurbaut, E., and Gingerich, P. D., 2004, Paleocene-Eocene carbon isotope excursion in organic carbon and pedogenic carbonate: direct comparison in a continental stratigraphic section: Geology, v. 32, p. 553-556.

McDougall, I., and Roksandic, Z., 1974, Total fusion ${ }^{40} \mathrm{Ar} /{ }^{39} \mathrm{Ar}$ ages using HIFAR reactor: Journal of the Geological Society of Australia, v. 21, p. 81-89. 
McKenna, M. C., 1980, Late Cretaceous and early Tertiary vertebrate paleontological reconnaissance, Togwotee Pass area, northwestern Wyoming, in Jacobs, L. L., editor, Essays in honor of Edwin Harris Colbert: Museum of Northern Arizona Press, p. 321-343.

NACSN, 1983, North American Stratigraphic Code, North American Commission on Stratigraphic Nomenclature: American Association of Petroleum Geologists Bulletin, v. 67, p. 841-875.

2005, North American Stratigraphic Code, North American Commission on Stratigraphic Nomenclature: American Association of Petroleum Geologists Bulletin, v. 89, p. 1547-1591.

Obradovich, J. D., and Hicks, J. F., 1999, A review of the isotopic calibration points for the geomagnetic polarity time scale, in the interval 83 to $33 \mathrm{Ma}$ (C34n to C13n): Geological Society of America Abstracts with Programs, v. 31, p. 71.

Ogg, J. G., and Smith, A. G., 2004, The geomagnetic polarity time scale, in Gradstein, F. M., Ogg, J. G., and Smith, A. G., editors, A Geologic Time Scale: Cambridge, Cambridge University Press, p. 63-86.

Patterson, B., 1939, New Pantodonta and Dinocerata from the upper Paleocene of western Colorado: Geological Series of the Field Museum of Natural History, v. 6, p. 351-384.

Renne, P. R., Swisher, C. C., Deino, A. L., Karner, D. B., Owens, T. L., and DePaolo, D. J., 1998, Intercalibration of standards, absolute ages and uncertainties in ${ }^{40} \mathrm{Ar} /{ }^{39} \mathrm{Ar}$ dating: Chemical Geology, v. 145 , p. $117-152$.

Repenning, C. A., 1967, Palearctic-Nearctic mammalian dispersal in the late Cenozoic, in Hopkins, D. M., editor, The Bering land bridge: Palo Alto, California, Stanford University Press, p. 288-311.

Robinson, P., and Ivy, L. D., 1994, Paromomyidae (?Dermoptera) from the Powder River Basin, Wyoming, and a discussion of microevolution in closely related species: The University of Wyoming, Contributions to Geology, v. 30, p. 91-115.

Röhl, U., Ogg, J. G., Geib, T. L., and Wefer, G., 2001, Astronomical calibration of the Danian time scale, in Kroon, D., Norris, R. D., and Klaus, A., editors, Western North Atlantic Paleogene and Cretaceous palaeoceanography: Geological Society of London Special Publication 183, p. 163-183.

Röhl, U., Norris, R. D., and Ogg, J. G., 2003, Cyclostratigraphy of upper Paleocene and lower Eocene sediments at Blake Nose Site 1051 (western North Atlantic), in Wing, S. L., Gingerich, P. D., and Schmitz, B., editors, Causes and consequences of globally warm climates in the early Paleogene: Geological Society of America Special Paper 369, p. 567-588.

Rose, K. D., 1980, Clarkforkian Land-Mammal Age: revised definition, zonation, and tentative intercontinental correlations: Science, v. 208, p. 744-746.

1981, The Clarkforkian Land-Mammal Age and mammalian faunal composition across the PaleoceneEocene boundary: University of Michigan Papers on Paleontology No. 26, 197 p.

Savage, D. E., and Russell, D. E., 1977, Comments on mammalian paleontologic stratigraphy and geochronology; Eocene stages and mammal ages of Europe and North America, Faunes de Mammifères du Paléogène D’Eurasie: Géobios, Mémoire Spécial 1, p. 47-56. 1983, Mammalian paleofaunas of the world: Reading, Addison-Wesley Publishing Company, 432 p.

Schoch, R. M., and Lucas, S. G., 1985, The phylogeny and classification of the Dinocerata (Mammalia, Eutheria): Bulletin of the Geological Institutions of the University of Uppsala (New Series), v. 11, p. 31-58.

Secord, R., ms, 2004, Late Paleocene biostratigraphy, isotope stratigraphy, and mammalian systematics of the northern Bighorn Basin, Wyoming: Ann Arbor, Michigan, University of Michigan, Ph.D. thesis, $532 \mathrm{p}$.

Simpson, G. G., 1928, A new mammalian fauna from the Fort Union of southern Montana: American Museum Novitates, v. 297, p. 1-15.

1929a, A collection of Paleocene mammals from Bear Creek, Montana: Annals of Carnegie Museum, v. 19 , p. $115-122$.

1929b, Third contribution to the Fort Union at Bear Creek, Montana: American Museum Novitates, v. 345 , p. $1-12$.

1935a, The Tiffany fauna, upper Paleocene. 1.-Multituberculata, Marsupialia, Insectivora, and ?Chiroptera: American Museum Novitates, p. 1-19.

1935b, The Tiffany fauna, upper Paleocene. II.-Structure and relationships of Plesiadapis: American Museum Novitates, p. 1-30.

— 1935c, The Tiffany fauna, upper Paleocene. III.-Primates, Carnivora, Condylarthra, and Amblypoda: American Museum Novitates, p. 1-28.

Smith, M. E., Singer, B., and Carroll, A., 2003, ${ }^{40} \mathrm{Ar} /{ }^{39} \mathrm{Ar}$ geochronology of the Eocene Green River Formation, Wyoming: Geological Society of America Bulletin, v. 115, p. 549-565.

2004, Reply: ${ }^{40} \mathrm{Ar} /{ }^{39} \mathrm{Ar}$ geochronology of the Eocene Green River Formation, Wyoming: Geological Society of America Bulletin, v. 116, p. 253-256.

Steiger, R. H., and Jäger, E., 1977, Subcommission on geochronology: convention on the use of decay constants in geo- and cosmochronology: Earth and Planetary Science Letters, v. 36, p. 359-362.

Stow, M. H., 1938, Dating Cretaceous-Eocene tectonic movements in the Bighorn Basin by heavy minerals: Geological Society of America Bulletin, v. 49, p. 731-762.

Swisher, C. C., and Knox, R. W. O'B., 1991, The age of the Paleocene/Eocene boundary: ${ }^{40} \mathrm{Ar} /{ }^{39} \mathrm{Ar}$ dating of the lower part of NP10, North Sea Basin and Denmark, International Geological Correlation Project 308: Brussels, Paleocene/Eocene boundary, International Annual Meeting and Field Conference, 2-6 December 1991, Abstracts with Program, p. 16.

Tauxe, L., and Watson, G., 1994, The fold test: an Eigen analysis approach: Earth and Planetary Science Letters, v. 122, p. 331-341.

Thewissen, J. G. M., 1990, Evolution of Paleocene and Eocene Phenacodontidae (Mammalia, Condylarthra): University of Michigan Papers on Paleontology No. 29, 107 p. 
Thewissen, J. G. M., and Gingerich, P. D., 1987, Systematics and evolution of Probathyopsis (Mammalia, Dinocerata) from the late Paleocene and early Eocene of western North America: Contributions from the Museum of Paleontology, University of Michigan, v. 27, p. 195-219.

Van Houten, F. B., 1944, Stratigraphy of the Willwood and Tatman formations in northwestern Wyoming: Geological Society of America Bulletin, v. 55, p. 165-210.

Van Valen, L., 1966, The Deltatheridia, a new order of mammals: Bulletin of the American Museum of Natural History, v. 132, p. 1-126.

Watson, G. S., 1956, A test for randomness of directions: Monthly Notices of the Royal Astronomical Society Geophysical Supplement, v. 7, p. 160-161.

Webster, M., Sadler, P. M., Kooser, M. A., and Fowler, E. M., 2003, Combining stratigraphic sections and museum collections to increase biostratigraphic resolution, in Harries, P. J., editor, High-resolution approaches in stratigraphic paleontology: Netherlands, Kluwer Academic Publishers, p. 96-128.

Wilf, P., Beard, K. C., Davies-Vollum, K. S., and Norejko, J. W., 1998, Portrait of a late Paleocene (early Clarkforkian) terrestrial ecosystem: Big Multi Quarry and associated strata, Washakie Basin, southwestern Wyoming: Palaios, v. 13, p. 514-532.

Williamson, T. E., 1996, The beginning of the age of mammals in the San Juan Basin, New Mexico: biostratigraphy and evolution of Paleocene mammals of the Nacimiento Formation: New Mexico Museum of Natural History and Science, p. 1-141.

Wing, S. L., Alroy, J., and Hickey, L. J., 1995, Plant and mammal diversity in the Paleocene to early Eocene of the Bighorn Basin: Palaeogeography, Palaeoclimatology, Palaeoecology, v. 115, p. 117-155.

Wing, S. L., Bao, H. M., and Koch, P. L., 2000, An early Eocene cool period? Evidence for continental cooling during the warmest part of the Cenozoic, in Huber, B. T., MacLeod, K., and Wing, S. L., editors, Warm Climates in Earth History: Cambridge, Cambridge University Press, p. 197-237.

Wood, C. B., Chaney, R. W., Clark, J., Colbert, E. H., Jepsen, G. L., Reeside, J. B., Jr., and Stock, C., 1941 , Nomenclature and correlation of the North American continental Tertiary: Geological Society of America Bulletin, v. 52, p. 1-48.

Woodburne, M. O., 1977, Definition and characterization in mammalian chronostratigraphy: Journal of Paleontology, v. 51, p. 220-234.

Yuretich, R. F., Hickey, L. J., Gregson, B. P., and Hsia, Y. L., 1984, Lacustrine deposits in the Paleocene Fort Union Formation, northern Bighorn Basin, Montana: Journal of Sedimentary Petrology, v. 54, p. 836852.

Zachos, J., Pagani, M., Sloan, L., Thomas, E., and Billups, K., 2001, Trends, rhythms, and aberrations in global climate 65 Ma to present: Science, v. 292, p. 686-693.

Zijderveld, J. D. A., 1967, A.C. demagnetization of rocks: analysis of results, in Collinson, D. W., Creer, K. M., and Runcorn, S. K., editors, Methods of palaeomagnetism: Amsterdam, Elsevier, p. 254-286. 